\title{
A 'Paradox of the Commons'? The Planning and Everyday Management of Green Point Park
}

Leani de Vries

DVRLEA001

A Minor Dissertation presented in partial fulfilment of the requirements for the degree of Master of Science in Environment, Society and Sustainability in the Department of Environmental and Geographical Science

Supervisor: Professor Sophie Oldfield

Faculty of Science

University of Cape Town

August 2016 
The copyright of this thesis vests in the author. No quotation from it or information derived from it is to be published without full acknowledgement of the source. The thesis is to be used for private study or noncommercial research purposes only.

Published by the University of Cape Town (UCT) in terms of the non-exclusive license granted to UCT by the author. 


\section{PLAGIARISM DECLARATION}

1. I know that plagiarism is wrong. Plagiarism is to use another's work and to pretend that it is one's own.

2. I have used the Harvard convention for citation and referencing. Each significant contribution to, and quotation in, this dissertation from the work, or works, of other people has been attributed, and has been cited and referenced.

3. This dissertation is my own work.

4. I have not allowed, and will not allow, anyone to copy my work with the intention of passing it off as his or her own work.

5. I declare that copying someone else's work, or part of it, is wrong, and declare that this is my own work.

Signature

Leani de Vries
Date

15 August 2016 


\section{ACKNOWLEDGEMENTS}

First and foremost, I would like to thank the Lord who has planted in me the dream, and provided me with courage to pursue my Master's at UCT. I did not walk this road alone and found strength in Him.

My supervisor, Sophie Oldfield, has welcomed me as a new and unfamiliar student with the most incredible knowledge and guidance and has been there for me every step of the way. Thank you for the passionate scholar that you are, your time, and for always believing in this thesis and in me. It has been such a pleasure to be your student!

I would also like to thank the various persons who were so willing to share their time and knowledge with me, allowing me to map more and more of the story told in this thesis.

To my parents and my twin sister. Thank you for the wonderful support system that you are, and have always been. Thank you for the prayers, the hugs, the daily phone calls and encouraging words. Most of all, thank you for allowing me the opportunity to spread my wings. 


\begin{abstract}
Cape Town's Green Point Park is a legacy of the 2010 FIFA World Cup, built on the then dilapidated, former Common. Initially heavily contested, it is now a beautiful, popular, and well-used public space that attracts diverse people from all over the city. The thesis narrates its paradoxical story by drawing on historical and archival data, park observations, a transect walk, as well as qualitative interviews with city planners, park management, service providers, and the formerly sceptical local public. First, the thesis reflects on the conflictual planning process that led to this new urban park and a changed vision and function for the Common. Second, it explores the park's everyday operation, the management and maintenance that are central to its present acceptance and safe, clean and pristine condition. I argue that the City's planning 'by exception' of the park, and the public-private management vehicle is central to its success and differentiates it from how others operate in the city. I suggest that this neoliberally planned and managed public park produces a paradox: it has restored this space once again as a usable and accessible public 'common'. This argument challenges a literature that assumes neoliberal forms of planning and regulation to limit, at best, or destroy urban spaces, resulting in a similar 'tragedy of the commons' (Hardin, 1968) or 'end of public space' (Sorkin, 1992; Mitchell, 1995). In contrast, the thesis builds on Jerram's (2015) critique in that the traditional commons too often become 'historical fantasy,' a theorised ideal and almost impossible reality, in the contemporary neoliberal era. This more nuanced assessment of the contemporary commons is important in the South African urban context, where there is great concern that neoliberal, market-led, world city agendas perpetuate exclusion and historical legacies of segregation (Marais, 2013). In a 'paradox of the commons', this publicly regulated, privately maintained free-to-the-public park has restored what was previously a Commons, albeit an unsafe and largely unused space. The Green Point Urban Park suggests a need to 'rethink' parks and their planning and management in contemporary and neoliberal post-apartheid South Africa. They do not necessarily result in a certain 'tragedy of the commons' or 'end of public space'.
\end{abstract}




\section{TABLE OF CONTENTS}

Plagiarism Declaration.................................................................ii

Acknowledgements..................................................................... iii

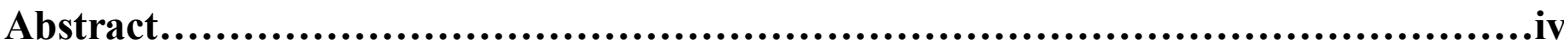

Abbreviations.......................................................................vii

List of Figures........................................................................viii

Chapter 1 Introduction............................................................................1

Chapter 2 Parks as a Contemporary Form of the Common? A Literature Review........5

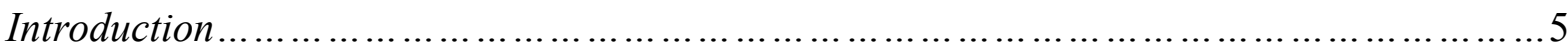

Parks and Public Space in Neoliberal and World-Class Cities ..................................5

Parks as Commons: 'Rethinking' the 'Fantasy' ..................................................

The Place of Parks, Public Space and the Commons in South African Cities....................12

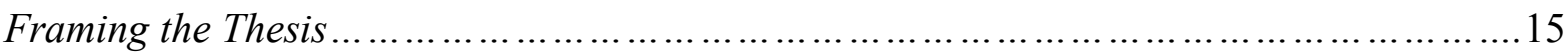

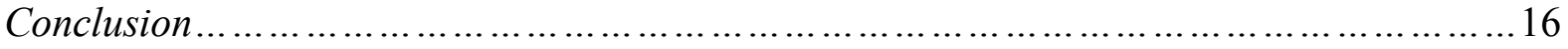

Chapter 3 Unpacking Green Point Park: A Chronology and the Methodology...........17

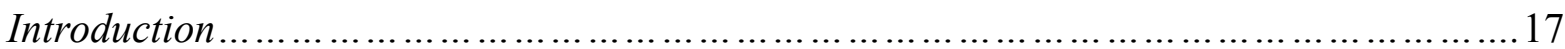

A Chronological Account: From Historic Common to 'Exceptional' Park ........................ 17

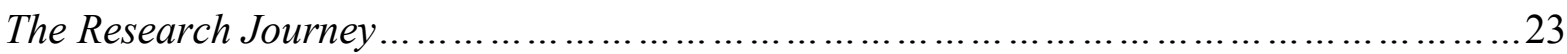

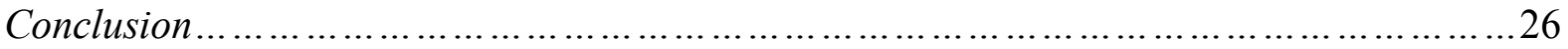

Chapter 4 From Common to Park: Planning by 'Exception' .............................27

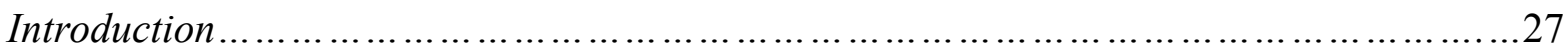

A New Urban Parkfor Green Point: 'Compensating’ Public Space .............................27

The Public Fight and Controversial Planning of the City's Neoliberal Endeavour..............28

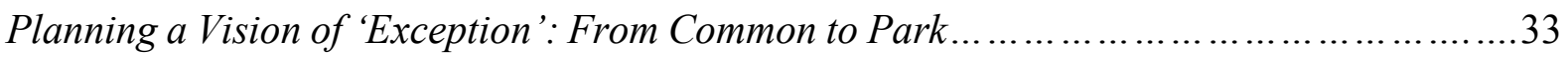


Conclusion.......

Chapter 5 The Park in Practice: Managing a Place of 'Exception' .........................38

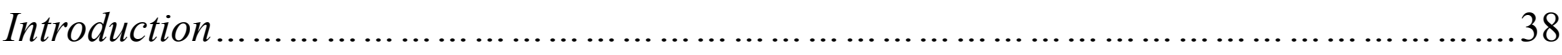

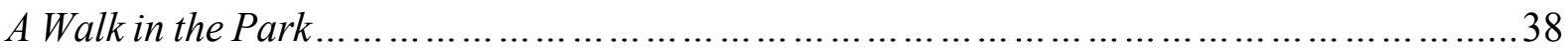

Up and Running: Managing a Place of 'Exception' '........................................42

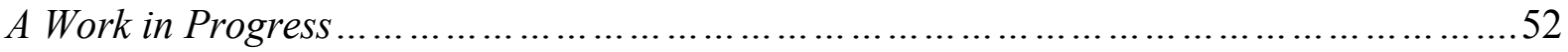

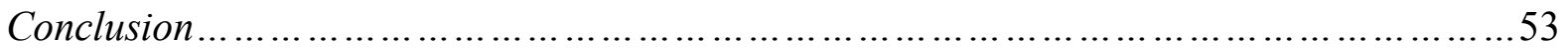

Chapter $6 \mathrm{~A}$ 'Paradox of the Commons'? In Conclusion.................................54

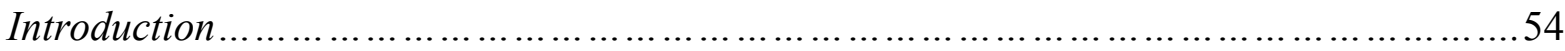

A Productive Mix: The City's Neoliberally Planned and Managed, 'Public' Park................54

The Restoration of a Commons: An Inclusive, Accessible and Free Park .........................57

A 'Paradox of the Commons'? In Conversation and 'Rethinking' the Literature ...................58

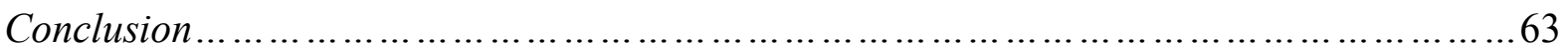

List of References...............................................................64

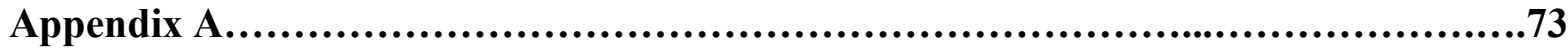




$\begin{array}{ll} & \\ \text { CEPA } & \text { CapBe Town Environmental Protection Association } \\ \text { FIFA } & \text { International Federation of Association Football } \\ \text { GEAR } & \text { Growth, Employment and Redistribution Programme } \\ \text { GPP } & \text { Green Point Park } \\ \text { GPRRA } & \text { Green Point Ratepayers' and Residents' Association } \\ \text { GPUP } & \text { Green Point Urban Park } \\ \text { I\&APs } & \text { Interested and Affected Parties } \\ \text { LED } & \text { Local Economic Development } \\ \text { MPRA } & \text { Mouille Point Ratepayers' Association } \\ \text { RDP } & \text { Reconstruction and Development Program } \\ \text { ROD } & \text { Record of Decision } \\ \text { USA } & \text { United States of America } \\ \text { VOC } & \text { Dutch East India Company }\end{array}$




\section{LIST OF FIGURES}

Figure 1: Green Point Park as seen from Signal Hill................................... 3

Figure 2: Green Point Camp during the Anglo Boer War.............................. 18

Figure 3: A photograph from the Cape Times Newspaper in 1932 with caption.............19

Figure 4: The seasonal 'vlei', Signal Hill and Lions Head.................................................19

Figure 5: Sketch of a dilapidated Common and nearby Green Point Lighthouse...............21

Figure 6: The beautiful Green Point Stadium and Green Point Park..................... 21

Figure 7: The old Green Point Common............................................... 34

Figure 8: The approved Concept Plan for GPUP................................... 35

Figure 9: The Green Point Park design............................................ .36

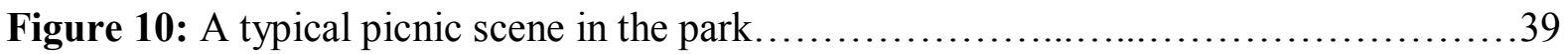

Figure 11: The Saturday Green Point Parkrun........................................40

Figure 12: The dome in the biodiversity showcase garden ............................ 41

Figure 13: A security guard sits in the shade by the lake............................. 47

Figure 14: A 'clean and pristine' adventure playground.............................50

Figure 15: Maintenance operations in progress.....................................52 


\section{Chapter One}

\section{Introduction}

Cape Town's Green Point Park was opened in 2011 as the compensatory 'legacy' of the 2010 FIFA Soccer World Cup, built on the then dilapidated, former Common and situated next to the Cape Town Stadium and other popular destinations such as the Victoria and Alfred Waterfront. Initially heavily contested by a local public with a deep concern over the historic Common, it is now a beautiful, free, safe, and well-used public space that boasts an appealing recreational, educational and 'green' character. Although in a privileged part of a postapartheid city characterised by inequality and division, this park is today a magnet for diverse urban residents, rich and poor, black and white, coming from all over Cape Town.

The thesis draws on historical and archival data, park observations, a transect walk, as well as qualitative interviews with city planners, park management, service providers, and the formerly sceptical local public, to narrate the paradoxical story of this park that embodies a South African place of 'exception'. First, the thesis reflects on the conflictual planning process in the build-up to the controversial World Cup and developments that led to this new urban park and a completely changed vision and function for the previously unregulated Common. Second, it explores the park's everyday operation, the public-private management and maintenance vehicle, and the host of dedicated workers such as the outsourced landscapers and security guards that are central to its present acceptance, nurturing, and safe, clean and pristine condition. It is the productive mix of these processes that informs my argument. I argue that the City's planning and management 'by exception', derived from its global pursuits, is central to this expensive park's success and differentiates it from how others operate in the city. I suggest that this neoliberally planned and managed public park produces a paradox: it has restored this historic space in Green Point, once again, as a usable, accessible and inclusive public 'common'.

This argument challenges a literature that assumes neoliberal forms of planning and regulation to limit, at best, or destroy urban spaces, resulting in a similar 'tragedy of the commons' (Hardin, 1968) or 'end of public space' (Sorkin, 1992). This reflects the position that parks, as important resources to changing urban environments, mirror or reveal time-specific ideals (Chiesura, 2004; Lawson, 2007; Marais, 2013). The debate focusses on the destructive effect of exclusive private and worldly city agendas on city space meant to be inclusive of all, but 
that become reserved for a particular, ideal user and use (Mitchell, 1995). In contrast to the foreclosing literature, the thesis builds on recent work on the urban commons that embraces the inherent complexities of contemporary cities to 'rethink' how these ought to exist (Borch \& Kornberger, 2015). I build on Jerram (2015)'s critique in that the traditional, unregulated and open commons too often become 'historical fantasy,' a theorised ideal and almost impossible reality, in the contemporary neoliberal era. I draw these insights to parks, that as public space, carry a similar 'struggle' but that some argue have replaced the rural commons to its unfortunate expense (Low, Taplin \& Scheld, 2005; Low \& Smith, 2006). This more nuanced assessment of the contemporary commons is important in the South African urban context, where there is great concern that neoliberal, market-led, world city agendas perpetuate exclusion and historical legacies of segregation in the new functioning of its spaces (Marais, 2013). It is useful, also since a gap exists in the park discourse that explores these larger debates in the context of the global South.

I propose that Green Point Park is a 'common', accessible and open to all in its safety and regulation. In a 'paradox of the commons', this publicly regulated, privately maintained freeto-the-public park has restored what was previously a Commons, albeit an unsafe and largely unused space. This highly expensive and beautiful metropolitan park, that was planned and managed 'by exception', has restored the 'publicness' and 'commonness' of this historic space into one perhaps now more inclusive and accessible than ever. The thesis provides a small, yet valuable case to 'rethink' parks, and their planning and management, in contemporary and contested neoliberal, post-apartheid South Africa. In this case, Green Point Park as a neoliberal and public 'legacy', has unfolded productively in its modern form of a commons and public space to suggest that these do not necessarily result in a certain 'tragedy' or 'end'. 


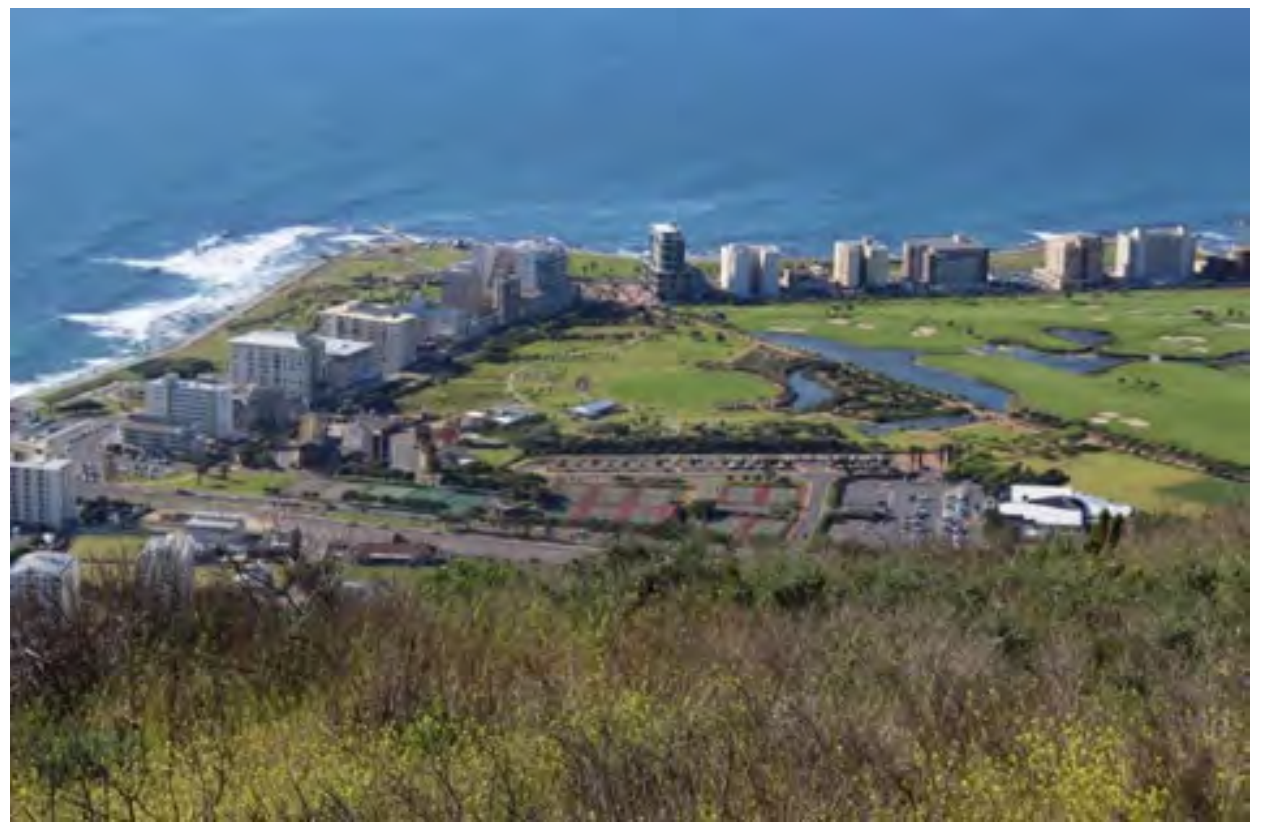

Figure 1: Green Point Park as seen from Signal Hill

By way of introducing the park (Figure 1), I provide a brief extract from my field notes below.

It is mid-March in Cape Town, between summer and autumn. I drive up to the main entrance where I, and several other eager families, are claiming parking spots. One family is climbing out of their car. It is packed with blankets, plastic tables, food and plastic cups and plates. Another young lady is putting a leash on her dog who is very excited to be taken for a walk.

I enter the packed park. A security guard is sitting in the shade at the entrance with a clipboard, paper and pen in hand. He looks tired and is rubbing his eyes. I walk past the lake. The waterwheel is turning, geese are lazing in the water, and beautiful purple waterlilies are in bloom. I enter the 'lighthouse promenade'. The red and white lighthouse is in front and the walkway is filled with cyclists, joggers and dogs on leashes. I turn into a section looking out on the golf course and lake where I sit. Golfers in golf carts are making their way to the next hole. I hear a mixture of sounds: birds chirping, water from the fountain, a helicopter, people talking, and children having fun. I also hear a very strong American accent walking past. There is a slight noise of construction coming from the residential area and the old man sitting on the bench next to mine is dazing away. I later make my way to the middle of the park. On the grassy area, a young man is doing yoga underneath a tree. Two cleaners outside the ablutions are sharing 
a joke. A security guard is sitting in the shade of an umbrella, observing the empty round lawn. The playground is filled with children of all ages. Moms and dads are sitting on blankets socialising with friends. One family has brought an inflatable soccer net and soccer ball and are playing on the grass. Next, I experience the row of picnic benches and tables that are each claimed and decorated with balloons and table cloths. The party supplies are being unpacked.

I go to the educational gardens. A hand full of visitors are admiring the storyboards and art. A young boy is in awe as his mother shows him around. A security guard is advising two children on their bicycles to stay on the paved areas only. I decide to leave the park after a little while. More families are entering with cooler bags and blankets in hand. I climb into my car, to the relief of another driver. There are now seven Golden Arrow busses parked outside and I just think, it is about to get even busier! (field notes: 12 March 2016)

The thesis is structured as follows. Chapter two forms the literature review in which I map a large local and global literary discourse on parks, public spaces, and the commons as they are theorized in the modern urban context. These are framed in a discussion on the contested postapartheid city and neoliberal era. I situate the case of Green Point Park in the wide body of literature. Chapter three presents a detailed overview of the rationale of the thesis where I introduce my methodological research journey and experience. It starts with a brief chronological and contextual overview of the history of this public land. In chapter four, I reflect on the recent transition from Green Point Common to Green Point Park. This involves exploration of the planning process 'by exception', embedded in the build-up and 'fight' to the World Cup and the City's development of a new stadium and urban park 'legacy' as compensation. It also presents some description of the new vision and function. Chapter five assumes a different tone and explores the 'park in practice', as observed through fieldwork, and the variety of 'actors' that 'nurture' the safe, clean and pristine park. I describe how a successful neoliberal and 'public' park is managed 'by exception' on a daily basis. The final, chapter six, concludes this thesis. First, it draws the empirical chapters together to conclude the park's story of 'exception' and productive neoliberal and 'public' mix. It then displays a paradoxical outcome in the way the regulated park has restored the old Common and is valued by the public today. Finally, I present my argument of a possible 'paradox of the commons' in conversation with the literature and reflect on how it contributes to a 'rethinking' of parks. 


\section{Chapter Two}

\section{Parks as a Contemporary Form of the Common? A Literature Review}

\section{Introduction}

In the urban environment, parks are considered to be important resources providing in the range of needs of the diverse public (Chiesura, 2004). A vast local and global literary discourse theorizes how parks unfold in the contemporary context. In this review, I map two overarching debates that inform understandings of parks and their current planning and management. These include parks as one of several forms of public space, and parks as contemporary forms of the common. Underlying these discussions is a shared concern over the effect of neoliberal and worldly city agendas on the diminished 'publicness' or 'commonness' of these spaces that are in essence, meant for all.

In this chapter, the paradoxically successful park in Green Point, is situated in conversation with these broader debates, later echoed in a scepticism of the post-apartheid city and perpetuated inequality in its spaces. It presents a foreclosing assumption in that neoliberal forms of regulation and planning by 'exception' limit or destroy public space and the commons, resulting in an 'end' or similar 'tragedy'. A body of research on the urban commons, however, necessitates a more flexible comprehension of the inherent complexities of the contemporary urban context to favour the case of this park. The literature review is ultimately brought together in a consideration of how the literary notions help shape a 'paradox of the commons', and a 'rethinking' of parks in the modern South African context.

\section{Parks and Public Space in Neoliberal and World-Class Cities}

In the first relevant body of literature, scholars converse upon notions of parks as one of several forms of public space, and the way these have changed in their 'public' meaning and function. A prevailing thread is the concern over detrimental neoliberal, and world-class, city agendas of 'exception'. As the dominant capitalist regime of the late 1970s, it is argued to exacerbate economic, social and spatial exclusion and polarization, also extending to the urban public space arena. Scholars suggest a private and 'market-led strategy' now manifests behind a facade of public interest and purpose (Brenner \& Theodor, 2002; Jessop, 2002; Miraftab, 2004a).

Neoliberalism is portrayed as an 'ideological apparatus', an 'agenda' by which we can interpret public space, and the inequality in the way these are planned and managed in cities today 
(Miraftab, 2004b; Marais, 2013). These are understood to have 'suffered the effects' of a neoliberal, urban agenda and its exclusive character. Resultantly, this literature questions whether parks remain 'truly public' (Fernández Álvarez, 2012; Mitchell, 1995). As the 'legacy' of an elaborate neoliberal endeavour, the case of this park tests these wider concerns.

The literature describes a changing responsibility in making public infrastructure, including parks, available and accessible in cities where the state has changed from primary service provider to service enabler that no longer carry the authority to rule and regulate (Minton, 2006; Miraftab, 2004a; Benit-Gbaffou; 2008). This is especially through privatisation or "the shifting of the planning and management of public spaces" to the private sector that instead carry their fate (Daneshpour \& Mahmoodpour, 2009:687).

In particular, the literature echoes the notion of public space coming to 'an end', originally coined by Sorkin in 1992. He designates American city spaces as 'theme parks' in that they appear to be inclusive, yet are heavily controlled. The 'end of public space' debate is not new and has since been either validated or challenged. While this thesis situates itself towards the latter, a foreclosing literature suggests such a depletion of 'public' space. A central notion is that of the 'other' or 'undesirables', where parks and public space are managed to regulate who and how they can and can't be used. This leads to them being 'clamped down' in the interest of order and safety, following a 'logic of special interests' to those considered 'legitimate' like a middle-class user. In such a complex 'politics of public space', a particular notion of who and what constitutes an 'appropriate public' and 'proper behaviour' is formulated and enforced (Low \& Smith, 2006; Doherty et al., 2008; Low, 2006). The idea that parks carry a city 'brand' to attract investment, links well here (Chan, Peters \& Marafa, 2015).

The 'appropriate public' are distinguished on the basis of characteristics such as income, gender, age, ethnicity and religion. This would exclude homeless persons, vagrants, beggars, prostitutes, drug users or others considered to be problematic or irrational (Mitchell, 1995; Minton, 2006; Daneshpour \& Mahmoodpour, 2009). Measures are subsequently put in place to remove or manage this 'threat' to the success and safety of the neoliberal city. These vary from toleration to exclusion by means of urban laws, privatization, security measures, surveillance and urban design. The latter is commonly associated with parks where the literature explores material exclusion through physical design such as single-seated benches, fencing or lighting that are less attractive for the 'others' or 'undesirables'. This is done in the interest of clean, safe and revitalised public spaces, restricting 'inappropriate' activities such 
as napping, begging, prostitution, selling illegal substances or drinking alcohol (Kimber, 2010; Mitchell \& Staeheli, 2006; Bergamaschi, Castrignanò \& De Rubertis, 2014; Bancroft, 2012; Low, 2006). Since Green Point Park itself is highly regulated, the empirical parts of this thesis explore what exactly this entails in this particular case to build on the discourse.

Mitchell (1995) introduces another less obvious 'other', namely political activists that challenge the order of planned public spaces and embrace freedom and disorder. This contest by the active public, is considered a necessary component in democratic societies (Miraftab, 2004a; Low, Taplin \& Scheld, 2005). By way of example, Mitchell (1995) traced the controversial history of Berkeley's People's Park in the United States of America (USA). It was highly celebrated for being an inclusive space to all, especially the homeless. Local activists however became unsettled by the plans of the city to develop it into a regulated space, implicating a loss of its 'publicness', and responded by extensive rioting. A similar contest is mirrored in the early story of Green Point Park, as the local community was sceptical about a change in structure of the old Common.

The discourse later points to the stressing question of what happens to those who are effectively denied a 'claim' to the city's now exclusive public spaces (Low \& Smith, 2006; Doherty et al., 2008). An unfortunate paradox is theorized when the very processes that exclude the unwanted, also perpetuate their existence by restricting access and leaving them unaccounted for in the only spaces they call home or negotiate daily life (Mitchell \& Staeheli, 2006; Bergamaschi, Castrignanò \& De Rubertis, 2014; Doherty et al., 2008).

Where public space was threatened by disuse and neglect in the past, the literature now responds to a commercial and private 'threat' (Low, 2006). The expansion of privatisation on parks ranges from less severe to full control. Examples include making parks more appealing to target users, moderate private control in the form of Business Improvement Districts, PublicPrivate Partnerships and Non-Profit Organizations, or full private ownership of profitgenerating parks (Madden, 2010; Minton, 2006; Miraftab, 2004b; More, 2005; Murray, 2010). I later illustrate how Green Point Park displays a rather unique structure.

Furthermore, the 'right to the city' debates stand in contrast with the 'other' or 'undesirables'. Broadly, it involves the right of the public to not only be present in city space but involved in its formation and decision making. Parks fit into the third generation category, which includes public social amenities (Parnell \& Pieterse, 2010). Katz (2006) states that privatization has replaced such a citizenship with a 'consumer-ship'. 'Privately public' spaces then remain in 
that they are "no longer really public in the sense of public space for all", following an "ethic of exclusion' (Mitchell \& Staeheli, 2006:153; Staeheli \& Mitchell, 2008).

Here, the discourse turns to public participation, often used to address questions of inclusion. Shuib, Hashim and Nasir (2015), for example, argue that the voice of the community who know their own needs, is essential for a successful park and ought to be expressed through a collaboration of community groups, planners and managers. Despite popular incorporation, it also yields scepticism. Differing 'typologies', motivations, actors and outcomes reflect a battle over private and public interests. The literature often portrays low and inappropriate levels of participation that form an alternative mechanism of exclusion through perpetuated private control (Nasir et al., 2012; Cornwall, 2008). Low, Taplin \& Scheld (2005) maintain that it is 'ethical' to sustain a 'citizenship' in parks through participation. In contrast, Miraftab (2004a) critiques community-based participation as mere symbolic justification for unchallenged neoliberal agendas and structures of physical exclusion. This thesis considers these arguments in the context of Green Point Park.

Other research on parks adopt a different position. In the case of Johannesburg's Joubert Park, Marais (2013) describes particular 'identity markers' on the basis of race, class, gender, sexuality and nationality that determine who the park is accessible to. The park was found to be a hub for lower-class black men. At the same time as a certain public being excluded, they also exclude themselves based on prejudices and the reading of 'identity markers'. Here, the meanings and imaginations attached to parks are just as crucial. Exclusion can also take the shape of avoidance from a perception or feeling. This strand of literature explores who claims parks to be their own and why, asking 'whose parks are they?' (Low \& Smith, 2006; Marais, 2013; Katz, 2006). Low, Taplin and Scheld (2005:199) explain that "People need to feel that a public park is for them" and would otherwise 'read' it as exclusive. I build on this literature, exploring the ways in which Green Point Park is claimed by the diverse urban public.

Reconsidering the original 'end of public space', scholars such as Madden (2010) argue for increasing complexity and reformulation of 'means' and 'ends', rather than its complete disappearance. Madden (2010:188) uses the case of Bryant Park in New York to identify a "publicity without democracy", centred on surveillance, control and consumption. In his exploration of the 'end of public space', Mitchell (1995:121) states that in its very nature, "public space was always a site for and a source of conflict" meaning that what defines public space, 'the public' remains a 'struggle'. Staeheli and Mitchell (2008:117) usefully explain that 
"Public space is a slippery, complicated, and shifting kind of space" where the tensions of exclusion and inclusion are always in the balance. It is also accepted that since public space exists in different forms, such as public streets, parks or plazas, its 'publicness' will also vary (Low \& Smith, 2006). Thus, even before the neoliberal era and its 'destructive' nature, universal understandings and 'truly public' spaces only ever existed as a theorized ideal or exception (Harvey, 2006).

Yet, even with such an understanding, hegemony and exclusion still encapsulate the strongest concerns of this debate that postulates the regulated user of public space as the mere consumer or spectator (Low, Taplin \& Scheld, 2005; Low, 2011). Harvey (2006) and Vainer (2016) provide useful terminology that I adopt in this thesis, describing a 'governance by spectacle' or 'planning by exception' to which public spaces are subject in the neoliberal city. Vainer (2016:104) states powerfully that "the city of exception plays to the dreams of the urban bourgeois" meaning that it serves only a certain legitimate public. In my use of the terminology, I explore what it means precisely in the context of this park. Marais (2013) suggests a linkage of a contested city with a contested park. While neoliberal Cape Town is portrayed as one such a contested city, this thesis allows a less foreclosing exploration in the context of a restored common. A second debate of relevance on 'the commons' is introduced below.

\section{Parks as Commons: 'Rethinking' the 'Fantasy'}

A second body of literature on 'the commons' provides another lens in which to theorize parks. Where the above section focused on parks as one form of public space, this section explores the ways in which parks are contemporary commons. This debate is relevant since Green Point Park now stands where the old and dilapidated Green Point Common used to be. The ways in which it functions as a restored 'common' today, is part of the focus of this thesis.

The notion of 'the commons' has re-emerged in the literature in recent decades, building on Hardin's (1968) popular account of the 'tragedy of the commons'. In this older, yet widely referenced work, he pins a fragile and fixed nature to the traditional, unplanned and open commons, subject to the threat of demise from unregulated and free use. In a significant part of his argument, Hardin (1968:1244) suggests that "Freedom in a common brings ruin to all". The ongoing debate is vast and conceptualisations of how and if 'the commons' could survive in the contemporary urban era are diverse, reflecting a rich body of work in which scholars map a 'struggle' and 'contestation'. It is important to consider that what counts as the commons ranges, and 'new' forms don't refer only to natural resources. These vary based on the actual 
common resource and boundaries, the institutions or rules surrounding them, and the communities using them. This could be anything from a school, river, digital information, or a park (Bollier, 2015; Dellenbaugh et al., 2015).

In the early literature, it is assumed that the traditional 'commons' is a declining or unfeasible phenomenon, contested between clashing parties with differing demands, or tricky to manage from inherent vulnerability. The literature concerns itself with how the commons is destroyed through privatization and enclosure, or local regulation and radical 'reclaiming' by the communities themselves (Foster \& Iaione, 2016; Hardin, 1968). Other scholars find promise in the traditional functioning of the commons and the 'hands-on' role of the free user to 'resist' neoliberal influences and self-govern (Bollier, 2015). The 'complex' commons debate theorizes how these notions of maintaining the commons relate to the particularly tough 'urban condition' (Dellenbaugh et al., 2015).

A more recent discourse on the 'urban commons' offers a useful addition to the above reviewed understandings. Scholars in this debate too postulate a change in their 'common' character, yet embrace this as part of the inherent dynamics of contemporary cities. Recent literature, such as the collection of work by Dellenbaugh et al. (2015), is useful in rethinking the 'fight' over the contemporary 'urban commons' by considering that what counts as 'the urban' and 'the commons', is constantly redefined. This 'moves beyond' the static notions that state and market are the only alternatives, and acknowledges that no set model exists for how the commons function. The arguments therein are however linked to a scepticism of the neoliberal reordering of cities and the enclosure of the commons. It makes a case for the commons to be 'claimed' through an insurgency and agency of the 'commoners' (Lamarca, 2015).

The edited volume by Borch and Kornberger (2015), however makes room for the paradoxical narrative of this thesis. This is so firstly in their agreement that the urban commons are not necessarily exhausted by consumption, but produced and enhanced by it. This means that in the dense city, the commons receive value not merely from existence or protection, but from the constructive activities that happen in them. This is reflected in the thesis whereby the Green Point Common became dilapidated from its lack of use and consumption.

Second, the authors propose the urban commons have its own 'power and politics' alongside its function within neoliberal society. This necessitates a consideration of the finer ways in which each individual common is produced uniquely. Nielsen (2015) describes an inevitable 'negotiation' that always involves some extent of contestation and exclusion. I find particular 
accordance with Jerram (2015). He criticizes the association of past commons as something to be recovered amid a modern, neoliberal enclosure and privatization, calling this a 'historical fantasy'. He explains that “... history shows that cities are too complex, that state and market are too woven into them, that they contain too much that is invisible and ungovernable, to make an 'urban commons' remotely plausible, in the form that activists inside and outside the academy wish for or theorize" (Jerram, 2015:64). This is crucial in the way it challenges static notions of the commons as a simple phenomenon. Bruun (2015) also challenges a 'simple narrative' in the literature that 'idealize' past commons or view them as 'inevitable tragedies'.

While the quintessential common and public space are not the same per se, these do intersect in the urban context. The literature implies that the traditional commons is controlled by 'the people', meaning that it is open, freely accessible and not owned by anyone. Public space, on the other hand, implicates the authority of 'the state' that owns and manages them. In the contemporary urban setting, however, both share a similar 'claim' and struggle for equitable access and 'right' in these spaces (Bruun, 2015; Staeheli \& Mitchell, 2008). Ever-evolving definitions of the commons and public space make both debates relevant to Green Point Park as a revived 'common' through the transformation to a neoliberal, yet 'public' park.

International studies also show a historical transformation of the shared commons into regulated parks. Low, Taplin and Scheld (2005) describe the very first urban parks in the USA as traditional commons for grazing, that later developed into a series of different park models serving certain purposes over time. Park models are however mostly theorized and associated with the global North (Loukaitou-Sideris, 1995; Low, Taplin \& Scheld, 2005; Marais, 2013). In a widely referenced account, Cranz (1982) suggests four phases of park models in the USA, summarised as; 'the pleasure ground' from 1850 to 1900, 'the reform park' from 1900 to 1930 , 'the recreational facility' from 1930-1965 and 'the open space system' from 1965. The first park model relates also to the 'landscape park' that promoted social reform, public health and refuge. The second served solely in the purpose of social reform, while the third model provided a strictly recreational service as 'municipal parks' with more 'specialised' playground equipment. On the other hand, the fourth open space system, contributed to the revitalisation of the city (Cranz, 1982; Low, Taplin \& Scheld, 2005). More recently, Cranz and Boland (2004) added the sustainable park as the fifth proposed model, from 1990 onward, emphasizing a shift in primary motives. While parks have historically served mostly social interests, priority is now afforded to an environmental and ecological contribution. In response, Low, Taplin and Scheld, (2005) propose a sixth park model, the 'culturally diverse park', where focus is instead 
given to the local community, their needs, culture and participation to merge social and ecologically sustainable park models and 'improve' contemporary parks.

Related to this, Davidson (2013) recognises two contrasting agendas in contemporary park design and management, namely sustainability or neoliberalism. The first supports an environmental motive while the second is economically driven and subject to the debates I explore. As displayed in this review, the literature precludes the notion that planned and regulated parks in their conversion of the traditional commons and subjectivity to the neoliberal era, can manifest favourably in the public's interest, pointing always to some form of exclusion, 'tragedy' or 'end'. Low and Smith (2006) therefore postulate an unfortunate expense of common land as it functioned historically. The discourse makes less room for a 'public' outcome in the contemporary, safety-conscious post-apartheid city where public space and parks are becoming more regulated and exclusive, and are subject to decline and a lack of proper provisioning (McConnachie \& Shackleton, 2010; Shackleton \& Blair, 2013; Marais, 2013). This thesis however explores the possibility of an opposite outcome.

I drew my initial rationale from Marais's (2013:21) assertion that "parks have been shown to reveal ideologies of time periods, social relations and government systems", meaning that they are direct products of the context in which they are situated. I also found use in considering that they "are not neutral spaces", but 'mirrors' of society filled with time-specific 'ideological messages' in their design and planning to afford each a unique purpose and character (Low, Taplin \& Scheld, 2005, Lawson, 2007; Marais, 2013). Yet, from the narrative of this park, I found accordance with the 'urban commons' thinking that moves away from a 'simple' narrative and 'historical fantasy' and accept a more complex dynamic at work for each unique park. This allows the paradoxical narrative of Green Point Park as a successful place of 'exception' that was brought to life by a neoliberal endeavour. I explore the significance of this in the contemporary, post-apartheid South African city.

\section{The Place of Parks, Public Space and the Commons in South African Cities}

The broad debates on urban spaces, whether 'public space' or the 'commons', is not limited to the developed world and is especially pertinent to post-apartheid South Africa. Green Point Park, as a park in neoliberal Cape Town, finds itself in this much-researched setting. The controversy around the city's spaces is deeply embedded in historical and contemporary South Africa and are underlined by questions of inclusion and exclusion. During apartheid, city space was segregated and the state, at national and metropolitan levels, put immense investment into 
strictly legislating and regulating access to spaces such as parks purely based on race (McConnachie \& Shackleton, 2010; Shackleton \& Blair, 2013).

Segregation culminated in all spaces, private and public, serving the sole interest of the white minority. The oppressed majority were valued only for the provision of labour in urban areas and were regulated as such. With this, non-whites weren't afforded the opportunity to freely express a citizen engagement in these spaces (Dawson, 2006). While considerable changes have occurred since the democratic transition, the literature is sceptical. Some local studies on public green space, for example, reveal their unjust availability, in terms of provision and distribution. (McConnachie, Shackleton \& McGregor, 2008; McConnachie \& Shackleton, 2010; Shackleton \& Blair, 2013).

With the inception of democracy in 1994, the oppressed majority was once again afforded access to public spaces such as parks and beaches (Houssay-Holzschuch \& Teppo, 2009). Yet, the literature presents South African cities as sites of persistent inequality where old gender, race and class hierarchies are reproduced (Spocter, 2005; Miraftab, 2004a). As such, Cape Town is described as "the city of unequal public spaces", "a city of divisions", "a place of great contrasts" and regrettably "South Africa's key aspiring Global City" (Houssay-Holzschuch \& Teppo, 2009:354; Lemanski, 2004:102, Southworth, n.d.:3; Lemanski, 2007:451).

The debate lies also in the adoption of neoliberal policies in the mid-1990s through the replacement of the Reconstruction and Development Program (RDP) with the Growth, Employment and Redistribution Programme (GEAR) and Local Economic Development (LED) strategies. These had a strong economic narrative and saw a change to decentralized governance. The issue was that this afforded increased private influence over the city's spaces (Didier, Peyroux, \& Morange, 2012, Lemanski, 2007; McDonald \& Smith, 2004). BenitGbaffou (2008) makes an interesting point, stating that the South African state has not so much lost its power as it has 'voluntarily released' it, to follow its economic agenda and shy away from issues of equality. Here, a strong similarity can be drawn to the global discourse on public space and concern for diminished 'public' purpose.

Ramoroka and Tsheola (2014:58) state that in South Africa too “...this privatization creates controlled, restricted and prohibitive access to public spaces and amenities". It is proposed that 'exclusionary practices' focusing on a particular public are persisting, but taking on alternative forms (Dirsuweit, 2007:2; Donaldson, 2014:5). Urban renewal schemes, road closures, gated developments, security complexes, privatized water services and surveillance measures are 
examples from the local literature. Here, a strong rhetoric of safety and security in postapartheid South Africa is displayed, but considered to be 'segregationist' and perpetuating unequal access and exclusion (Dirsuweit, 2007; Donaldson, 2014; Ramoroka \& Tsheola, 2014; Narsiah, 2013; Spocter, 2005; Lemanski, 2007, Miraftab, 2007; Benit-Gbaffou, 2008). Unfortunately, there is a lack of research on how this unfolds in the particular form of parks in South Africa.

Another relevant argument to the local debate is made by scholars such as Dirsuweit (2007), Lemanski (2007), Miraftab (2007) and Marais (2013). They make mention of the recent trend in African cities, such as Cape Town and Johannesburg, that aspire to attain world-class or global status. Here, a link can be drawn with above-mentioned 'planning by exception' and 'governance by spectacle'. These cities are generally perceived to be in pursuit of conflicting social and economic ideals. Green Point Park sits usefully as the 'legacy' of one such a South African city's world-class pursuit, in the form of the World Cup, offering a productive mix of neoliberal agendas, while also making available and accessible, 'public' space.

Another body of literature on 'mega-events' must be introduced here and is similar in the assumption of an underlying exclusionary practice. Relevant to the case of this park, Cornelissen and Swart (2006), identify a post-apartheid 'drive' for mega-events as a 'tool' of reconciliation. Mega-events such as the Olympic Games and FIFA World Cups are notoriously spectacular and extraordinary, appealing to a certain global society. The host nation is subject to the same invented ideal that accommodates and requires a particular international audience and 'ideal' spectator. An ambiguous 'mega-event ecology' is theorized where hosts are left with mixed 'legacies', some beneficial like urban regeneration and others detrimental like huge economic costs (Roche, 2000; Andranovich, Burbank \& Heying, 2001; Horne \& Manzenreiter, 2006). Locally, urban architecture, infrastructure and public services are among the many aspects of the transformed city. The new urban environment is described as a 'fantasy city', 'imaged commodity' or 'bourgeois playground' (Horne \& Manzenreiter, 2006; Andranovich, Burbank \& Heying, 2001). These notions are relatable to the controversial way in which Green Point Park became the barter and 'legacy' of a South African city's much contested event.

Driven by a fear of increased crime and the 'other', the local discourse also points to a perpetuated state of separation and inequality in contemporary South African society and its highly protected city spaces that are controlled and regulated in terms of who and how it can and can't be used (Samara, 2011; Dawson, 2006). These notions build on the global discourse 
and place parks, public space, and the commons in what is understood to be a particularly unequal and exclusive local setting. As a suitable case study, this thesis explores these debates.

\section{Framing the Thesis}

Using Green Point Park as my research topic, I was interested in 'public' parks and how these are understood in the contemporary, urban and post-apartheid context. Following a lack of research that intersects these topics, I was able to explore three relevant bodies of global and local literature and posit the park and outcomes of the thesis as a valuable literary contribution. Using two broad debates on parks as public space and parks as a modern form of the commons, a foreclosing discussion on the 'end' or 'tragedy' of these came to the fore, with concerns over exclusive neoliberal and world-class city agendas that diminish their 'public' purpose. In an extended debate, a changed and safety paranoid South African society reflects this discourse in its perpetually exclusive spaces. The city of Cape Town is subject to much of this discussion. This thesis is framed in particular conversation with some key voices.

I build on the notions of Marais (2013) and Lawson (2007), that parks mirror and reveal timespecific ideologies of cities and reflect how exactly Vainer's (2016) 'planning by exception' and Harvey's (2006) 'governance by spectacle' unfolded in the specific planning and management of this neoliberally driven park. This furthers Mitchell's (1995) notions of a constant struggle over the city's parks and public spaces and Low, Taplin and Scheld (2005)'s concern with the newest 'threat' to what should be socially and culturally inclusive urban parks. In the particularly contested post-apartheid setting, this thesis is also in conversation and adds to the work of Marais (2013) on Johannesburg's Joubert Park that mirrored the literary concerns of an exclusive and 'socially conservative' South Africa.

In a 'paradox of the commons', I found favour with the recent 'rethinking' of the urban commons, in reference to this park's prior existence as the dilapidated Green Point Common (Borch \& Kornberger, 2015). I build on the powerful statement of Jerram (2016) who criticizes a 'historical fantasy' of the traditional, unregulated common and welcomes an approach that allows for the commons, even in their contemporary and regulated neoliberal form, to be productive and not necessarily come to an 'end' or 'tragedy'. This revelation makes room for inherent urban complexities and is significant in the way it stretches and softens interpretations of unequal and exclusive South African city space. 


\section{Conclusion}

This literature review has mapped the local and global debates on parks as they relate to the commons and public space and are framed in a discussion on the South African city, neoliberalism and associated contestation. In the large and foreclosing discourse, there is a strong case that suggests these spaces have suffered from the neoliberal threat of regulation and exclusivity that determine the way they are envisioned and managed to accommodate very particular, private interests and reduce their core 'public' and 'common' essence. The literature points to the 'impoverishment' of public space and previously existing commons through a new, neoliberal threat (Low, 2006). I later find accordance with the body of research on the urban commons that necessitates a more flexible understanding of these notions in the inherent complexities of the contemporary urban context. This is also useful when considering the park positioned in a post-apartheid city, and the issues around city space that are deeply embedded. My thesis builds on this discourse to unpack Green Point Park, its planning and management by 'exception', and the paradoxically productive way in which these have come together in what resembles a contemporary 'paradox of the commons'. 


\section{Chapter Three}

\section{Unpacking Green Point Park: A Chronology and the Methodology}

\section{Introduction}

In the discourse on parks, public space and the commons, there is a large debate around how these manifest in the contemporary urban context. This debate is foreclosing in a conceptualisation of their demise through the threats of neoliberal, private and world city agendas, and is especially relevant to the post-apartheid city. By exploring Cape Town's 'exceptional' Green Point Park (GPP), this thesis provides a contribution from the global South to bring in conversation with local and international literature.

The aim of my research is to narrate this park's story. How it came to be, and what it takes every day to uphold it. I unpack how a contested, neoliberal legacy has come together in a 'paradox of the commons'. It was my first objective to investigate details 'on the park': the history, 'actors' and thought processes behind a space that was controversially transformed from the Common into the larger Green Point Urban Park (GPUP). My second objective was to explore the daily workings 'in the park', which involves a mix of neoliberal and public mechanisms, and hard-working 'actors' that are crucial to its maintenance. In this chapter, I first provide a brief chronological overview of this historic space. This lends context and informs my methodological approach. I then describe the analytical design of the thesis and literary framework that shaped my specific methods. I reflect on how the narrative developed and share my personal research journey.

\section{A Chronological Account: From Historic Common to 'Exceptional' Park}

A crucial element to the park, and analytical design of this thesis, relates to the rich history of this land that has evolved in its 'public' form and function throughout time. I present some background to this, and the most recent transition from common to park.

Initially, during the precolonial period, the land was used freely by local people for the grazing of cattle and livestock. Some of the earliest history involves the Khoikhoi that camped and hunted on the grounds. Cape Town was later colonized by the Dutch from 1652 to 1806 . The Dutch East India Company (VOC) used the land ${ }^{1}$ for the grazing of the Company's cattle

\footnotetext{
${ }^{1}$ The larger area was called 'de Waterplaats' (the foreshore or waterfront), in the $18^{\text {th }}$ century. In the early $19^{\text {th }}$ century it was named 'de vlakte genaamd de Groene Punt' from which 'Green Point' emerged (Todeschini and Japha Architects and Planners, 1991).
} 
(Todeschini and Japha Architects and Planners, 1991; van Papendorp, 2010a; Patrick \& Clift, 2006). British colonialization followed immediately after, and the land was used for the AngloBoer War from 1899 to 1902 (Figure 2). It was also used for the other wars of the $20^{\text {th }}$ century (Green, 1948; Bickford-Smith et al.,1999).

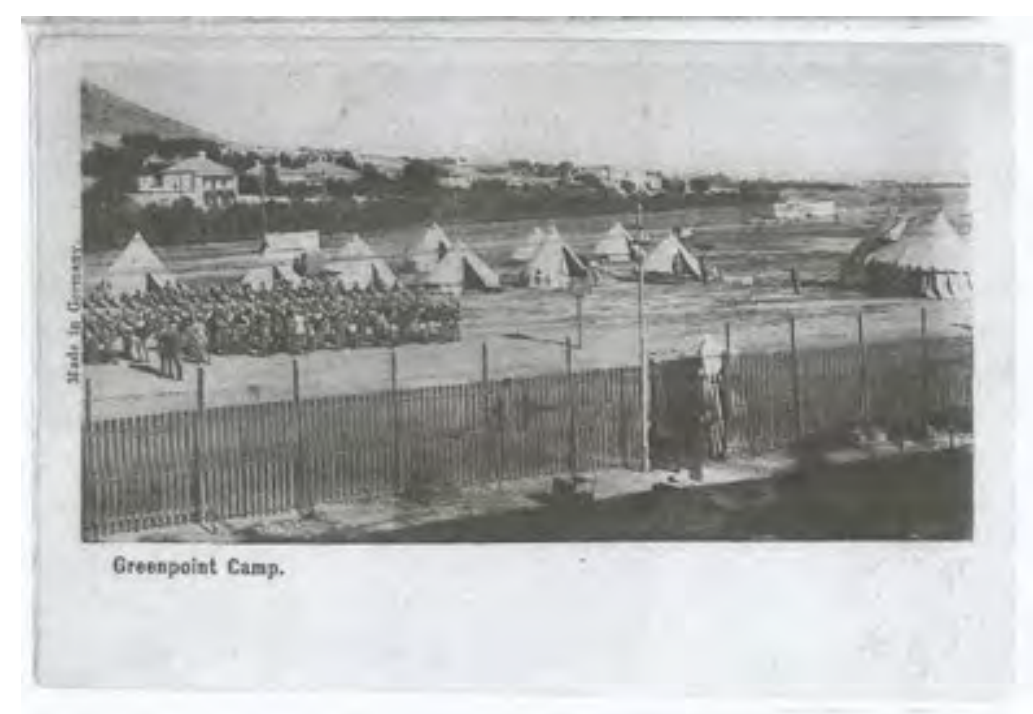

Figure 2: Green Point Camp during the Anglo-Boer War (National Library of South Africa, Cape Town Campus)

Perhaps the most significant moment, was when Erf 1056 Green Point was granted to the Cape Town City Council by King George V and the Union Government in 1923, to become public land for the purpose of recreation and sport, and to officially become a commonage (van Papendorp, 2010a). There is great, local, importance attached to this creation of the Green Point Common. It had since kept its function but also saw a decline in some of its historic 'common' uses. For example, the area used to serve as land where Table Valley, Sea Point and Green Point residents came together socially. Dairy farmers also utilised the area closest to Beach Road until the 1930s (Figure 3). The City introduced alternative, and private, land uses including defence, health, educational, residential and transport that gradually reduced the size of the Common (Todeschini and Japha Architects and Planners, 1991; Patrick \& Clift, 2006). From as early as this time, concern centred around ongoing threats to the Common. 


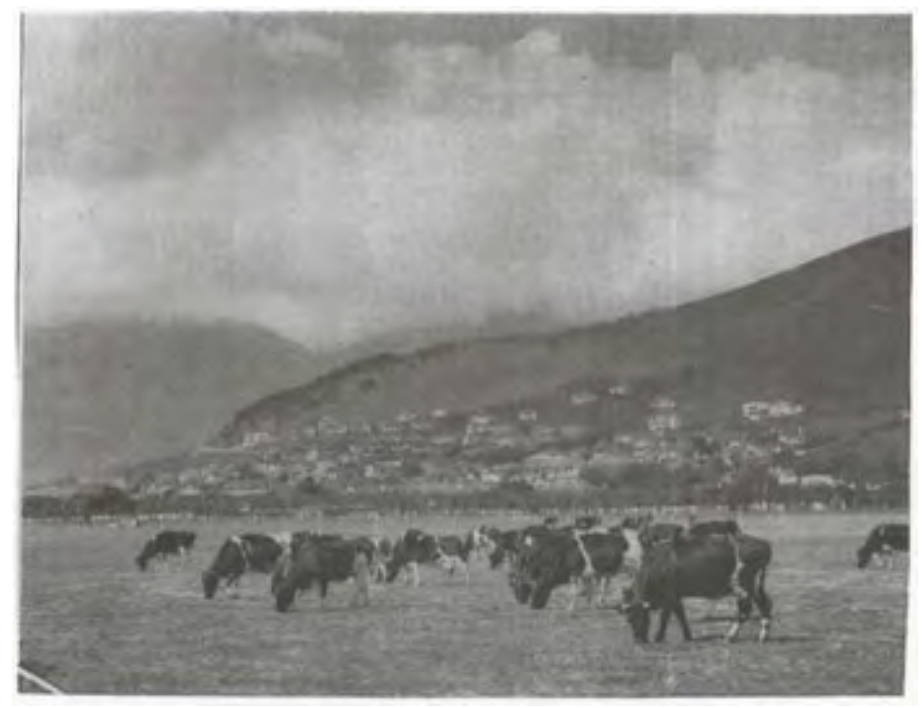

Figure 3: A photograph from the Cape Times Newspaper in 1932 with caption - "SOON TO BE BARRED? - A familiar scene on Green Point Common. Dairymen of Mouille Point and Three Anchor Bay, whose cows have grazed on the Common for many years, are seriously perturbed by the proposal of the City Council to enclose part of the Common for Sports and recreation" (National Library of South Africa, Cape Town Campus)

Nevertheless, the Common is fondly remembered for many historical sport and recreational moments. In one example, it was the site of early horse racing in Cape Town before the Kenilworth Racecourse opened in 1882 (Patrick \& Clift, 2006). A seasonal 'vlei' was situated in the centre of the race course (Figure 4). The sport was introduced by British army officers in the 1790s, and races were held two times a year in Autumn and Spring (Worden et al., 1998; Green, 1948). Later, it became more competitive amongst both rich and poor, and slaves started to compete as jockeys. Worden et al. (1998) refers to these events as 'multi-ethnic', suggesting how the entire town came together.

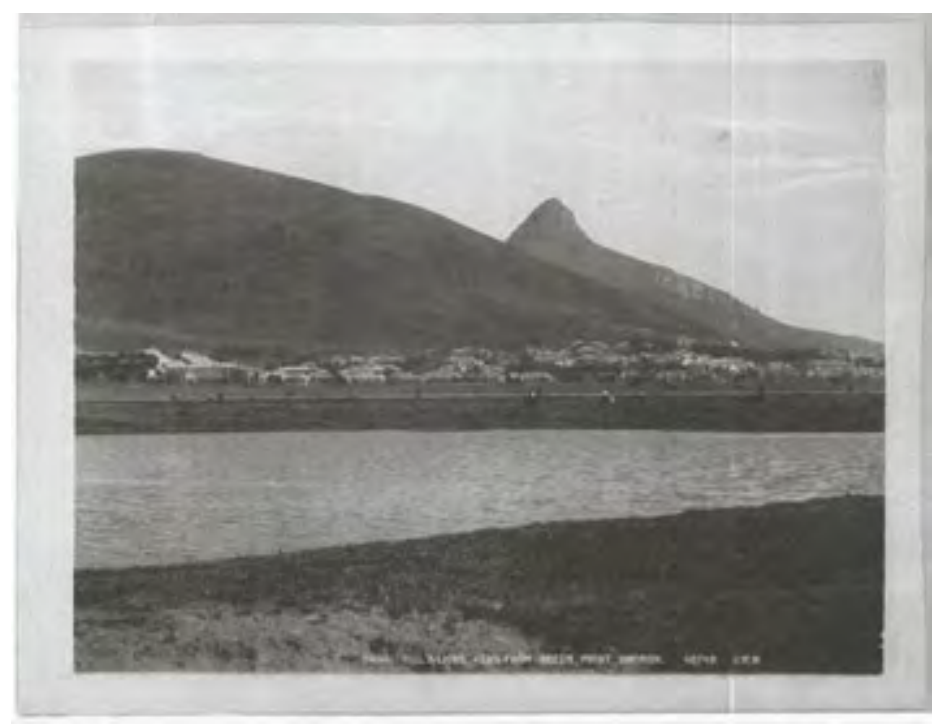

Figure 4: The seasonal 'vlei', Signal Hill and Lions Head (National Library of South Africa, Cape Town Campus) 
The Common was also used for canoeing and boat racing. Regattas were hosted in winter at until the early 1900s. Furthermore, the Common also hosted some of the earliest rugby and cricket matches from the late 1800s, enjoyed by officers and civilians (Todeschini and Japha Architects and Planners, 1991; Patrick \& Clift, 2006; Worden et al., 1998). Athletics and cycling emerged when the Green Point Track was built at the end of the $19^{\text {th }}$ century. A golf course was established in 1895 but was rebuilt to become the Metropolitan Golf Course after 1902. Hockey, baseball, football, tennis and bowls are other associated sports codes. Important social and cultural events were also held at the Common. Examples include the first Coon Carnival in 1907 to celebrate the New Year and the 1934 Historical Pageant that commemorated 100 years since the emancipation of slaves (Patrick \& Clift, 2006; Todeschini and Japha Architects and Planners, 1991; Bickford-Smith et al., 1999).

A next era was in store for the Common as private recreational use increased substantially from the mid- $20^{\text {th }}$ century. The biggest concern thereafter was the gradual loss of its 'commonness' and public accessibility (Figure 5). For a considerable amount of time, the 'eroding' Common had an unfavourable reputation. It was greatly underutilised and in need of an upgrade. A once vibrant space had fallen into a 'low time' and became 'dysfunctional' and 'dangerous' (JVP, interview: 28 September 2016; PVH, interview: 5 October 2015). Broken fences, broken glass, potholes, squatters and drug lords are among the associations with the old Common, considered to be a "waste of space". The City remained interested, developing visions and concept plans, but struggled to implement them (KLF, interview: 9 February 2016; PVH, interview: 23 February 2016).

The narrative of this thesis, is informed by starkly contrasting pictures such as the ones below. It considers how the space officially declared 'public' in 1923, has seen a complete turnaround in the beautiful and well-used, yet neoliberal and regulated park. The GPUP precinct hosts the newly built Green Point Stadium and Green Point Park (Figure 6). At any given time, vast numbers of people take part in some kind of sporting or recreational activity, visiting the park or attending an event. 


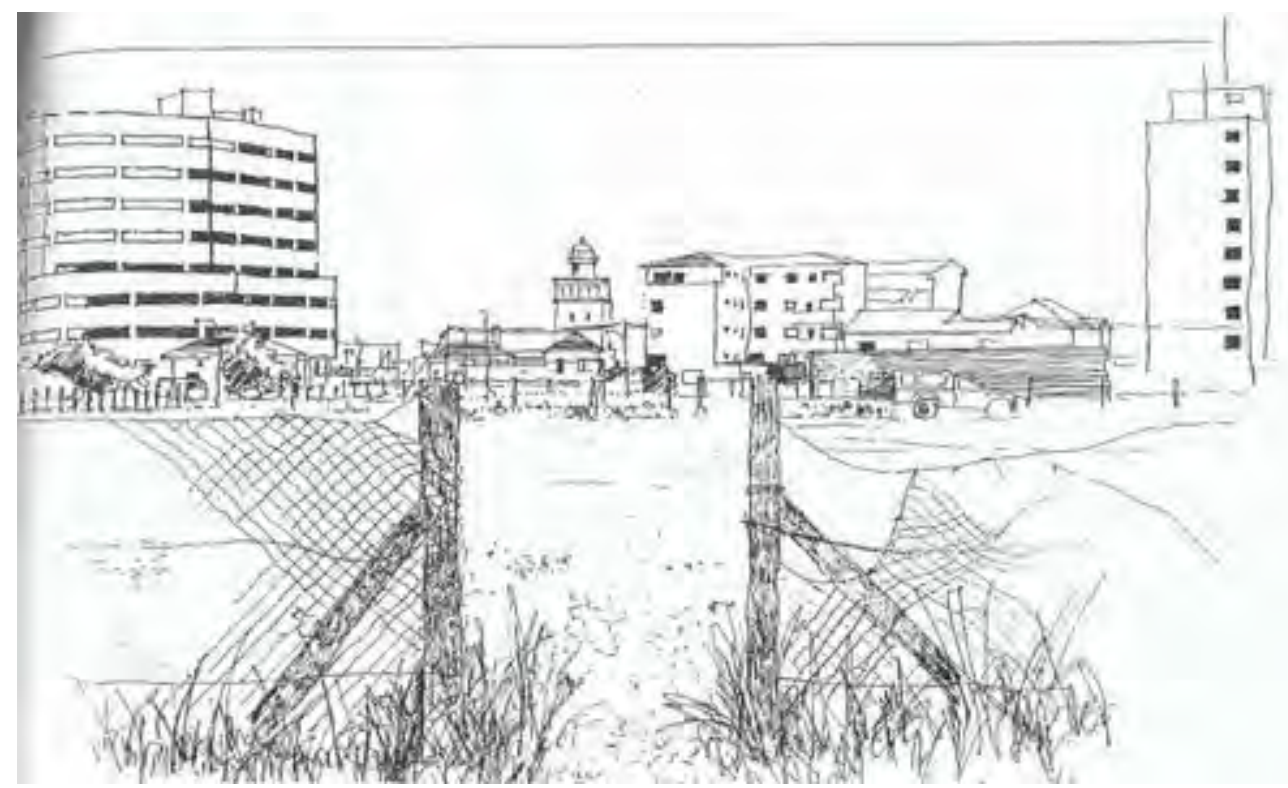

Figure 5: Sketch of a dilapidated Common and nearby Green Point Lighthouse (Todeschini and Japha Architects and Planners, 1991:59)

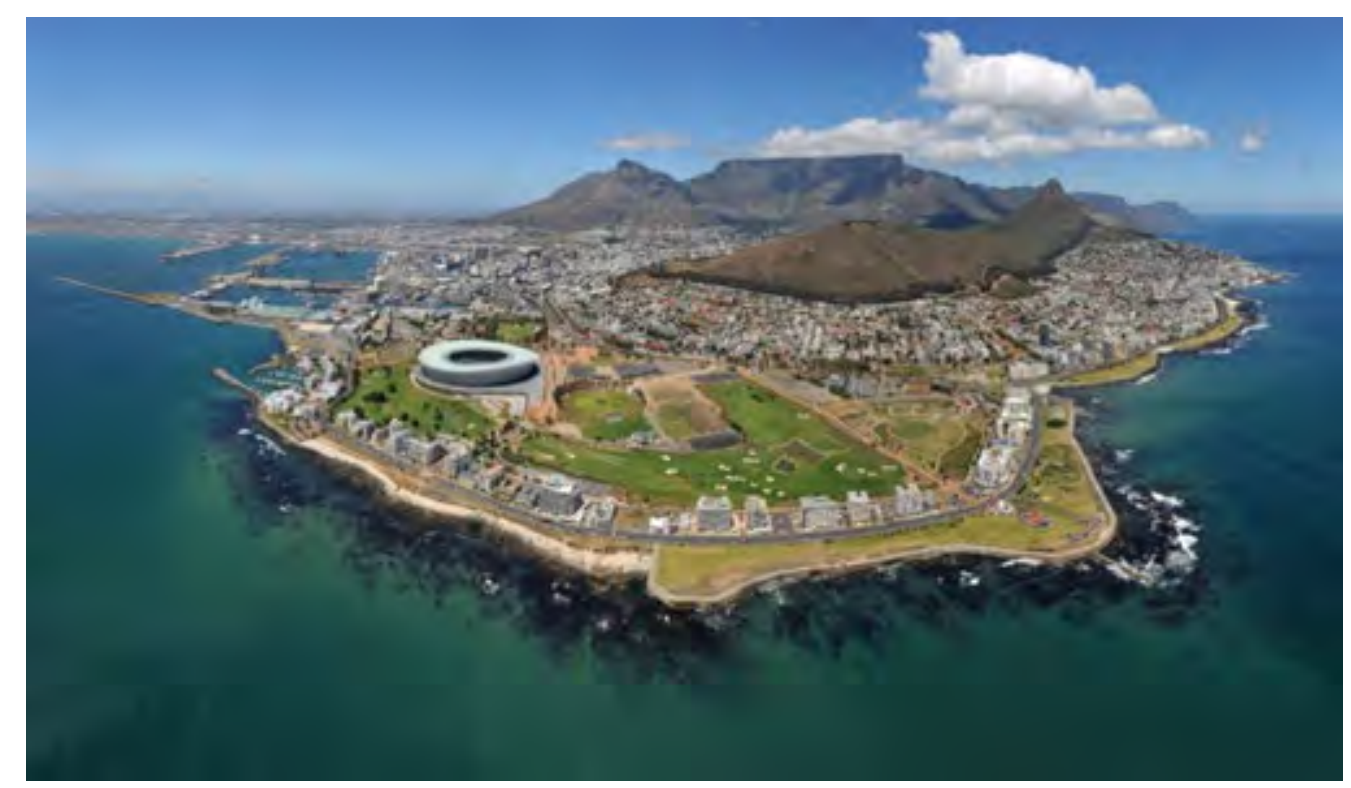

Figure 6: The beautiful Green Point Stadium and Green Point Park (Photograph by Bruce Sutherland)

The park, at the heart of this thesis, can trace its beginnings to the country's hosting of the 2010 FIFA World Cup, in one of its most elaborate endeavours. When South Africa won the bid, the City of Cape Town was commisioned as one of the nine host cities to plan and succesfully present a total of eight matches for the round-robin group stages, a quarter final and a semifinal that could seat 68000 people. This implicated a massive political drive and financial opportunity for upgraded public infrastructure as funding was made available by the national, provincial and local governments (PVH, interview: 5 October 2015). 
Yet, the selection of a location saw a massive public dispute as Green Point was not the City's first choice. Concern centred around the costly construction of a new stadium as opposed to areas with already existing venues or in need of economic development and investment such as Newlands and Athlone. Nevertheless, the Common was hand-picked by FIFA in 2006 as the preferred site due to its "prime location to showcase the city". It was nestled amongst the beautiful Table Mountain and ocean, and lacked any unwanted sights (Chain \& Swart, 2010:154).

The first Record of Decision (ROD) was issued by the Minister for Environment, Planning, and Economic Development in January 2007. The City prioritized the global spectacle and then the deliverance of a public "legacy' "that would last forever" (PVH, interview: 23 February 2016). This included a R578 million reconfiguration project to create GPUP. The R4.2 billion Cape Town Stadium had to be completed by December 2009. The larger reconfiguration commenced in January 2009 (PVH, interview: 5 October 2015). This included major storm water works, roadworks on the Granger Bay traffic circle, the MyCiTi integrated rapid transport system, the Fan Mile, the construction of shared sports fields, the renovation of the athletics track, reconfiguration of previous clubhouses and boundaries to accommodate the seven sports codes (PVH, interview: 5 October 2015). The 12.5 ha GPP, a R45 million project itself, was opened in February 2011 as the 'public space element' (van Heerden, 2009; Pollack, 2011). This included a R22 million reduction of the metropolitan golf course, as well as a project to redirect water into the urban park from the city's historic water source. Water from underground 'grachts' now reaches the lakes in the park and golf course from an underground pipe (Papendorp, 2010b). Significantly, van Papendorp (2010a:1) explains that the mega-event served as "the catalyst to realise the City of Cape Town's long-standing vision for the Common". Green Point now boasts a new urban park claimed to be a 'world class events facility' and 'green jewel' (City of Cape Town, 2012). It has stimulated the regeneration of the inner city, upgraded public infrastructure and boosted local residential property values (PVH, interview: 23 February 2016). Although managed as a large financial investment, the City is also struggling to secure the economic viability of the stadium that some call a 'white elephant' (Phakathi, 2013).

Despite initial controversy, this thesis shows a paradoxical restoration of the Common in the 'exceptional' park. The historical account above crucially foregrounds my research journey and final argument. 


\section{The Research Journey}

My research journey was flexible, allowing the analytical design to develop more precisely as I unpacked the story and 'actors'. What started as an exploration of the park's production and governance, developed into a paradoxical narrative of how its planning by 'exception' and unique management came together. The thesis focused on unpacking the park, by exploring the planning and how this 'exception' also translates to its daily maintenance. After consideration of these processes, and the underlying story of a transformed place, I could return to the literary questions of how the commons and public space manifest in contemporary cities. In situating my argument and 'paradox of the commons', it also contributes to a deeper understanding and 'rethinking' of parks in the post-apartheid city.

In terms of my methodological framework, I was guided by the ethnographic studies of Marais (2013) and Low, Taplin and Scheld (2005), conducted on urban parks in South Africa and the USA. They assert that an ethnographic understanding of parks, affords an underpinning of the park as a 'place'. From their methodological reasoning, I devised what I call a modified 'park ethnography'. The scholars maintain the relevance of qualitative, ethnographic research techniques in studying parks. This involves a creative exploration of the research topic and site by being present and engaged to gain a comprehensive understanding.

In pursuing my objectives, Low, Taplin and Scheld (2005) were useful in suggesting a 'Rapid Ethnographic Assessment Procedures (REAP) methodology', most appropriate for researching parks. This consists of a list of different methods, typically conducted by more than one researcher and for an extensive period of time. My methodological approach is 'modified' as I selected particular 'rapid methods' to suit my outcomes, scope and timeframe. A proper 'park ethnography', with a strong anthropological undertone, would focus on local persons and the way the park is being used and perceived. My research was focused rather on how the park was planned and managed by 'exception' to unfold in a favourable way.

I first explored secondary sources, in the form of historical and archival data. What was the Common like and how did it function before? My trips to the Cape Town Campus of the National Library of South Africa as well as the Special Collections Libraries of the University of Cape Town, revealed this rich history and granted necessary context. From the aging archival photographs, postcards, posters, rich descriptions and sketches in books, I could obtain a greater sense of the space that has served the citizens of Cape Town in some capacity, for 
centuries over. The majority of my methods however involved primary data collection and fieldwork, where I was present in the study space and interacted with the relevant 'actors'. Ethics approval was granted from the Faculty of Science for this portion of the thesis where I became somewhat of an investigator; gathering information, asking questions, making notes and observations to tease out and map the paradoxical story.

As I am not originally from Cape Town, I was not familiar with the park. I had heard of it and was recommended to visit. This left me intrigued. My first contact with the park was therefore as the researcher and unsuspecting park explorer. In the subsequent participant observation, that I conducted for the duration of about six months during spring of 2015 and summer and autumn of 2016, I could crucially familiarise myself with the 'site'. What is this park like? How does it function every day? What makes it unique? Marais (2013) suggests that recording information, participating and making observations provides necessary depth to the researcher's understanding of the park and methodological approach. This involves attention to both ordinary and extraordinary happenings. Low, Taplin and Scheld (2005) recommend that the researcher keep a field journal in which notes are made of 'everyday life in the park'. I conducted participant observation arbitrarily, by visiting at various times and days of the week and positioning myself at different areas of the park. I chose this approach as it was clear that the park was not static. I kept my field journal and pen with me, making notes of any mundane or interesting happening. My observations ranged from what the park users were doing and saying to how the various workers were operating or even what the weather was like. I kept a camera with me to take photos as well. At times, I usefully separated myself from my researching position, by inviting friends with me to have a picnic or eat ice-cream. On those occasions, I was instead, just another park user.

In the next two methods, I conducted what Low, Taplin and Scheld (2005) describes as 'expert' and 'individual' interviews. The former involves communication with those who have some sort of 'special expertise', while the latter involves communication with individuals closer to the 'site'. I started with the former by conducting more formal types of interviews with several relevant stakeholders willing to share their valuable opinions and information. The interviews were arranged in advance and semi-structured. I prepared questions before hand, but allowed space for further discussion of topics as they emerged during the meetings. Here, I was particularly interested in uncovering the thinking and unfolding of this park, its planning, management and the tensions in the balance. What was the idea behind the park, and the legacy of the World Cup? How was the public involved? What does it take for the park to be a success? 
How is it received today in light of the old Common? How does it compare to other parks in the city? I fortunately didn't struggle to secure interviews or build contacts. This led me to communications with the landscape architect, the City's planning director, the park/ facilities manager, several committee members of the local Residents' Associations of Mouille Point and Green Point, as well as former operations managers at the City's Department of Sport and Recreation and City Parks. During these sessions, of between one to two hours each, I was welcomed with openness and honesty. I approached this method in two phases. The first set of interviews were conducted in 2015 and were instrumental in gaining an initial comprehension of the park. The final set of interviews were conducted in 2016 and served usefully as 'tests' and follow-up conversations that allowed me to fill in the blanks and explore the tensions.

The latter instalment of interviews, the so-called 'individual interviews', occurred much later and were more informal. They were aimed at gathering information from 'actors' 'in the park', particularly the security guards, landscapers and cleaners. These persons were crucial in my understanding of the detailed work that is ploughed into keeping the park safe, clean and pristine every day. In an effort to avoid intimidating the staff, these took the shape of casual conversation and questioning. They were also not set prior to the actual conversation. Instead, I approached individual workers in their work environment, during operation hours. Weekdays were ultimately the most appropriate time to do so, as the park was much quieter and the workers were more approachable and less busy. In total, I interviewed eight security guards, four landscapers and three cleaners occupied with particular tasks in different parts of the park. I was received with smiles and an openness to share some of their valuable time. This friendliness and interaction with the park user is very much part of the ethos and was a great relief to me as a desperate researcher. How exactly is the park kept safe, clean and pristine? What are the difficulties of the job? Is this 'your' park too? However, some interviews were less useful, at times even awkward. I was on a few occasions denied a conversation due to the worker being too busy or uninterested, but was always directed to another person. In a useful addition to these interviews, I also engaged with some park users. This served as a 'test' to explore some of the public's motivations behind visiting the park, their impressions and experiences, also considering the Common before. I kept diversity in mind in terms of ages, genders, ethnicities, park use etc.

In the final addition to my modified methodology, I conducted a 'transect walk'. Low, Taplin and Scheld (2005) explain that this forms a 'guided walk' through the span of the park, alongside a knowledgeable consultant who provides comments and expertise. I enlisted the 
help of the park manager. This was a particularly exciting venture as we drove around the park in a golf cart. The 'transect walk' lasted two hours in which I directed him on where to go and probed various questions to which he responded with explanation and examples. What is the biggest challenge in this part of the park? What do the workers do here? This method was useful to better understand the park on the ground.

\section{Conclusion}

In this chapter, I present an overview of the rationale of this thesis. I introduce my particular research journey, experience and the case study of a historic place that informed it. I first provide a brief contextual and chronological overview to illustrate how this space has evolved in its 'public' and 'common' character throughout time and then proceed with reflections on my methodological research journey and how the thesis developed. I explain my 'modified', qualitative methods that led to an unpacking of the paradoxical story and 'actors'. In the following chapters, I display how the park's new found 'commonality' and 'publicness' unfolds paradoxically in a post-apartheid, neoliberal city to situate in conversation with the larger literary debates on the commons and public space in the urban context. 


\section{Chapter Four}

\section{From Common to Park: Planning by 'Exception'}

\section{Introduction}

While Green Point Park is today a successful place of 'exception' in post-apartheid Cape Town, the change from common to park was particularly controversial. This planning process seemingly echoes some of the literary concerns on diminishing 'public' purpose and its effect on 'public' space in the neoliberal era. In this chapter, I reflect on the conflictual planning process, embedded in the build-up and public 'fight' to the World Cup and the City's development of a new urban park 'legacy' as compensation. I also consider the vision employed by the City in the complete reconfiguration of the old Common into a multi-purpose and 'world-class' urban park from which the public park, and its new functional structure, came to life. I explore a contentious time in the evolution of Green Point's public space, that was driven by a neoliberal planning agenda and set it apart as an 'exception' for parks in the wider metropole.

\section{A New Urban Park for Green Point: 'Compensating' Public Space}

The time prior to the World Cup and its accompanying public 'legacy', was one of immense pressure within this host city (PVH, interview: 5 October 2015). In this section, I consider the City's neoliberal bartering with public space as compensation for its largely disputed endeavour. I show later how the planning process of 'exception', perceivably skewed priorities and public 'fight', reflect a neoliberal city agenda that sparked initial difficulty in the balancing of public and City interests. In the mix was the potential success of a re-envisioned public space and its new functional arrangement. These aspects in the story of the park seemingly resemble a local and global debate that asserts unfavourable 'public' outcomes for cities and their spaces, especially modern South Africa, that participate in a demanding mega-event politics and planning by 'exception'.

The City was left in the predicament of balancing its goals of growth and global exposure with the strict requirements of its international clients, FIFA, as well as the needs of Interested and Affected Parties (I\&APs), and the responsibility of translating the endeavour into a long-term 'legacy' for the metropolitan public (PVH, interview: 5 October 2015). The ultimate hostvenue was not where the City had originally hoped (Chain \& Swart, 2010). A portion of the dilapidated Common and metropolitan golf course, nestled in an elite part of Cape Town with 
its beautiful natural surroundings, later became the preferred site for a brand new stadium and left the City in an "awkward position" (JL, interview: 23 April 2016). The political motivation was however there to accommodate the non-negotiable demands of its clients, sparking an immediate public dispute from concerned members of the surrounding community and environmental groups.

The controversial build-up to the World Cup included several individual objections and appeals as well as a lawsuit-scare that threatened to halt the entire production process (PVH, interview: 5 October 2015). In an effort to see through the imminent event and mitigate a strong public 'fight', the City made good on a promise to deliver a new, international quality urban park 'legacy' that would satisfy the recreation and sporting needs of the entire metropole and become a 'long-term public asset' (PVH, interview: 5 October 2015). The current Chair of the Green Point Residents' and Ratepayers' Association (GPRRA), describes the park usefully as the "carrot" that eased the public outcry (JM, interview: 23 February 2016). In an 'exception', this park was planned completely anew, and not by the usual City authority, from the drive of a global event and as compensation in an already privileged area. It was an "expensive compromise", a significant capital investment, for the sceptical local public who weren't interested in any changes to the Common in the first place. The more than 3500 parks that are planned and managed by City Parks have either existed for years or are newly built in areas that require an upgrade or greater provision of public space like Athlone or Khayelitsha. Low resource capacity also does not allow this to happen regularly (DG, interview: 4 July 2016).

This bartering is described by some as the City's 'begging' for public acceptance at that time. This was successful, and many were effectively persuaded (JL, interview: 23 April 2016). The prospect of a new and international quality park is described as the "real turning point" in this contentious time (KLF, interview: 9 February 2016). What makes this bit of context relevant, is that the promise of a public 'legacy' in the form of an urban park indeed served as successful compensation for an undesired event.

\section{The Public Fight and Controversial Planning of the City's Neoliberal Endeavour}

Despite controversy around the location of the venue, the plans of the City to host the World Cup and build a new stadium and urban park 'legacy', was carried through. This section considers the particularly local fight that ensued during the planning process, and the role that the very passionate local as well as metropolitan public were afforded. 
The metropolitan public was first informed of the City's proposed intention to 'rezone' the Common in 2006 through widespread media coverage, and was invited to attend an 'open house day', two 'public meetings' and two 'focus group meetings' in May, April and August as well as register as I\&APs through notices that appeared in various newspapers. Other means of communication included emails, letters, posters and information sheets to those who responded. Public libraries and internet websites also made relevant reports available (City of Cape Town, 2006). As part of the first ROD and per routine Environmental Impact Assessment requirement, the City developed a six-month 'metropolitan-wide' public participation strategy. This was approved by the Minister in March 2007 and involved weekly and monthly consultations with I\&APs, to discuss design and implementations (PVH, interview: 5 October 2015). A Green Point Urban Park Forum was subsequently established where stakeholders such as the independent sports clubs and ratepayers' associations met for discussion (LS, interview: 2 February 2016). The participation process also involved public meetings and workshops held at a total of twelve different venues across the metropole. These meetings were held in 2007 during the months of March, April and May in Atlantis, Woodstock, Gugulethu, Mitchell's Plein, Muizenberg, Athlone, Green Point, Strand, Parow, Khayelitsha, Kraaifontein and the Bo-Kaap (PVH, interview: 5 October 2015; City of Cape Town, 2007).

The public participation process was designed to involve the entire metropolitan public in some way and to collaborate with relevant stakeholders (PVH, interview: 5 October 2015). Yet, the specific strategy of the City made provision only for public input and comment which left little room for participation in the actual design and planning processes. These larger responsibilities were given to several appointed experts (LS, interview: 2 February 2016). Media headlines read, for example, in the "park for the people", "everyone is invited to have a say at meetings about Green Point Common's new urban park" (City of Cape Town, 2007:1). The period for public comment closed a year later, in March 2008, after which the assessment of public input or 'say' began, and a final ROD was issued (van Heerden, 2008).

In especially the contemporary South African context, where the urban public is a heterogeneous mix of people with different needs and opinions, a unanimous outcome from this process was unexpected. As such, while the developments around the urban park and stadium were generally disputed, I could establish in my interviews that even the Green Point community did not share similar concerns. Some did not even care at all and had a relatively positive outlook on the World Cup (KLF, interview: 9 February 2016). The current Vice-Chair of GPRRA explained that this might have something to do with a "high level road division" 
where those living above the road are significantly more affected by sound on the Common than others and were therefore more concerned (LS, interview: 2 February 2016).

Nevertheless, my investigations revealed a public 'fight' against the City's plans as some members of the local community were initially highly sceptical and frustrated by the imminent spectacle (JL, interview: 23 April 2016). Just over 1300 objections were registered after the first announcements (Chain \& Swart, 2010). A separate ratepayers' association was also established in the wake of the event, per suggestion of a local councillor, to address the area specific issues at hand for suburb of Green Point (JL, interview: 23 April 2016). During this time, it was the opinion of the ratepayers' association that "big things were happening" (JM, interview: 23 February 2016). One might find the local 'fight' and scepticism unusual, considering it had already been an elite and commercialising part of the city, and that the investment could improve a dilapidated Common. Yet, it was exactly their desire to preserve the Common and prevent its further demise that sparked their passion.

The greatest concerns, according to the former Chair of GPRRA, were the perceived "threat to the Common" and issues around the physical changes and environmental effects that such a large-scale event would bring. It was assumed that more of the Common would give way to the plans of the City and that the area would attract greater numbers of people and events (JL, interview: 23 April 2016). In one interview, the real "existence value" that the community attached to the Common is highlighted (DG, interview: 4 July 2016). Some members felt that new endeavours were not evenly balanced throughout the city and that Green Point was becoming the prime spot for commercial developments (KLF, interview: 9 February 2016). A large point of debate was around the perceived 'commercialisation' of Green Point as the local public feared the Common would become a "commercial hotspot" and not fulfil its "public space potential'. It was especially undesired because such spaces like the Waterfront already existed in the vicinity, and the Common was already shrinking (JM, interview: 23 February 2016). Though the Common became underutilised and "less than ideal", there was always the hope that it could be a "great public space" (JL, interview: 23 April 2016).

A long list of issues was raised. The most significant were impacts on the local community adjacent to the Common. Traffic, noise, visual impact, financial viability and environmental sustainability were among those brought up in the interviews and related both to the event as well as the future 'legacy'. The prospect of crime, vagrants and other issues of safety and security also formed part of the immediate, event-related concerns (Chain \& Swart, 2010). To 
many, these developments were a large and unwanted 'disruption' (JM, interview: 23 February 2016). The community was also highly concerned with construction and how the actual event proceedings would change normal, everyday life and the historic Common. The historic 'public' functioning of the Common, in its historic delineation of sport and recreation, is crucial (JVP, interview: 28 September 2015). The previous Chair of the Mouille Point Ratepayers' Association (MPRA), shares that "we were concerned about losing the Green Point Common", describing it as an 'uncertain' and 'anxious' time (MVE, interview: 18 May 2016).

A further source of public frustration came from the perceived failure of the City to involve the local public in the actual planning and conceptualisation of the urban park. Some individuals felt that they weren't afforded a strong enough voice and participation in the physical planning process and felt excluded. In my interview with a former operations manager of City Parks, I could confirm this 'exception'. Most parks in the city, especially the smaller parks and 'smart parks' are planned to fit the unique needs of the community that are also actively involved in the process and vision. She explains that it helps in "creating an identity for the community" (DG, interview: 4 July 2016). It was the opinion of the ratepayers' association that they had put a lot of hours into ideas for this development, at the top of their agenda for years, but that these were eventually just discarded. An example was the notion to make the public park much bigger in size (JL, interview: 23 April 2016; JM, interview: 23 February 2016). The current vice-chair of GPRRA also says that "there was no space for design inputs" or the incorporation of suggestions. In another example, he mentioned that the Forum was centred only around administrative issues. He personally felt that the City followed a very closed, top-down approach saying that it was "kind of disappointing" that "nobody really listens to the input of the public". It was believed that little room was made for taking the preparations and ideas of the very 'curious' and 'intrigued' public seriously, and that the developments occurred in a rather rushed fashion (LS, interview: 2 February 2016).

In my interview with the City's planning director, I could confirm this strategy and resultant friction between the City and some members of the public. He discloses that it was their approach to appoint a multi-disciplinary team of experts to oversee the very demanding stadium preparations and urban park development for the successful hosting of the World Cup first, and then the future benefit of the metropole. This meant that internal, operational and technical project management teams as well as an external team of consultants were enlisted to plan and deliver the required infrastructure on time. This included engineers, urban designers, landscape planners and architects, and other experts. Van Heerden (2014) explains that these teams were 
in charge of formulating the overall vision, aim, design principles, objectives and appropriate uses for the new urban park. This too, I view as a planning 'exception' in the complete linkage of the park with the wider urban park precinct and the expertise and creativity of external and internal professionals specifically recruited for the World Cup (JVP, interview: 28 September 2015). In general, the planning for public parks in the city are the responsibility of City Parks. The Department was however never solicited in what some consider an "exclusive operation", and somewhat "offensive" decision (DG, interview: 4 July 2016).

The planning director maintains that it was "the City's thing", but also an immense challenge to manage the mandate of their clients with that of the individual citizens (PVH, interview: 5 October 2015). He acknowledges that the public participation did not run as smoothly as intended. In one example, he explains that for the meeting set to gather input from the public in Athlone, no one showed up. While, on the other hand, he felt that those from the surrounding community wanted to control the process themselves. There was a challenge with balancing the local and city level intent of the development. Here, he pointed to the problem of people trying to deliver inputs that just "weren't close enough to the project". This is an interesting 'exception' to the community approach of City Parks where those living closest to these public spaces are considered the first to involve (DM, interview: 28 June 2016). He explains that the design and the construction was "not for the ratepayers of Green Point just because they lived there", making reference to the fact that the park was not just a local one (PVH, interview: 23 February 2016). In our interview, the past Chair of GPRRA argues that while they always recognised that the urban park was for the public benefit of the entire Cape Town, with it being in their backyard, they had the contextual knowledge. He explains that "we are Green Point and we live here", that "it is particularly important to us because we know and understand the area". It was their position, that they ought to have been involved first-hand in the vision and design processes. This was not to deny wider metropolitan interest, but due to their direct concern of the area. Here, reference is made to the historical significance of the Common. It is his opinion that the City officials operated like they thought they knew more than the public (JL, interview: 23 April 2016). There was however some successful collaboration with the local community. The past Chair of the MPRA explains that while they were initially concerned during what started out as a 'difficult time' with lots of complaints, they became more informed and accepting of the ongoing developments. This came with realisation of the 'bigger picture' of the urban park. Also, he is of the opinion that the City was very responsive to the Mouille 
Point community's demands. They were also later involved in raising funds with the City to contribute and 'sponsor' the outdoor Labyrinth (MVE, interview: 18 May 2016).

Yet, from the interviews, it is clear that a strong air of antagonism ensued between some of the role players during this time of the planning. The greatest opposition came however from the Cape Town Environmental Protection Association (CEPA) which threatened to stop all developments by way of protests and taking high-court action (Chain \& Swart, 2010). The Association identifies as a "public interest organisation". In a significant statement in their written appeal, CEPA argued that "It is thus scarcely an exaggeration to say that the entire process has been stampeded to an undignified consummation, in the interest of satisfying a deadline arbitrarily imposed in distant Zurich." (Jarvis, 2007: 14). The concern was that the City skewed its public priorities for their own neoliberal interests and international clients. The Association touched on all the above local frustrations but also found fault in the way that the City made their decisions in a hasty fashion. They maintained that the relevant steps were not taken as effectively as possible, due to the political pressure of prioritizing the successful hosting of World Cup and the wishes of its clients. While the urban park did form the City's barter, there was further scepticism about how it would turn out, whether the promise of an international quality urban park would be delivered and is viable in the long-term future (JL, interview: 23 April 2016). This scepticism is not widespread in my interviews and for the most part, the prospect of the park was a successful compensation.

Above I have displayed how the controversial process in the build-up to the World Cup borrowed the park a planning 'by exception'. It was part of an unusual process of compensation, was not carried out by the usual City Parks authority, and did not directly incorporate the local community in the actual planning and vision of the park.

\section{Planning a Vision of 'Exception': From Common to Park}

Despite the City's conflictual and 'exceptional' planning process, these developments were set to continue and a vision for the Common was put in place. Here, I reflect on this change of vision for the Common and its function to become a pretty, safe and regulated 'public' park in the form of the larger GPUP and Green Point Urban Park. 


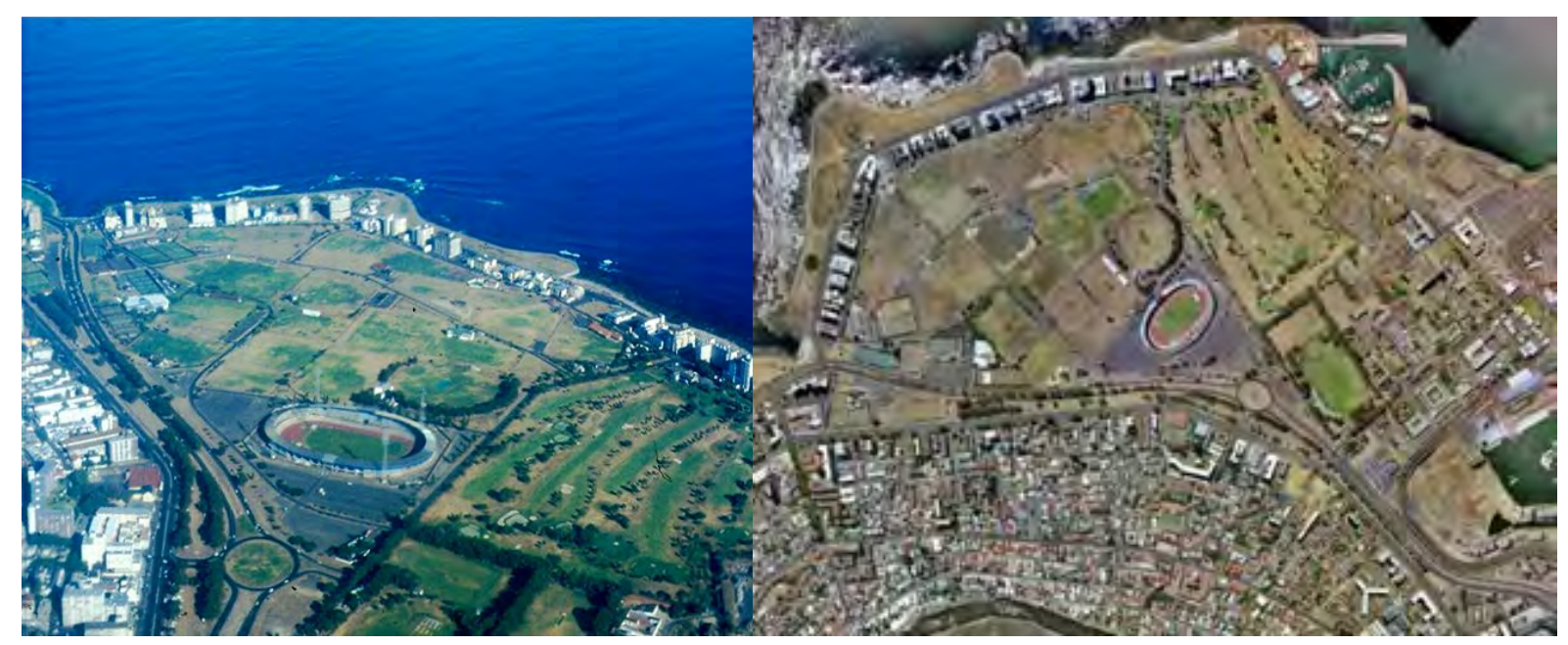

Figure 7: The old Green Point Common (van Heerden, 2012)

While Green Point 'lost' its Common in the way it used to function, the City's neoliberal vision contributed to the entire metropole 'gaining' a new 'international-quality' and multi-purpose urban park in its place (Figure 7). My interview with a former operations manager of City Parks was useful in highlighting that each park in the city embodies their own "experience". There is no blue print and each carries a unique value. While this park is not necessarily a significant 'exception' in the City or by international standards, the circumstances around its planning and subsequent vision and function was based on an 'exception'. This park, as the 'legacy' of a contested event, needed to be 'sold', not just to the local community, but to the entire city and beyond. (DG, interview: 4 July 2016).

The contemporary GPUP mirrors the City's vision for the precinct to display an element of 'exception', worldliness, safety, and regulation. This is a complete change to the unregulated and dilapidating function of the old Common. This new vision 'from common to park' is recorded in the final ROD that was issued by the Minister in June 2008 along with the approval of the final concept plan (Figure 8). This did not simply involve a new stadium for the World Cup, but a major reconfiguration of the geometrical layout of the urban park and surrounds (van Heerden, 2009).

"To create a multi-purpose open space and sports complex that will accommodate a range of sports codes and sporting facilities of an international status as well as local facilities meeting Metropolitan and local recreational pursuits offering a relief to inner city inhabitants - the Urban Park becoming a public amenity of Metropolitan significance and a space for intercultural social integration - serving the broader Cape Town community now and in the future" (van Heerden, 2009). 
To facilitate this vision, the City identified and employed a very particular set of principles in alignment to its larger ideals of creating a safe, inclusive and sustainable city that accommodates the social needs of its heterogeneous citizens in a transparent fashion. These principles formed the basis for the entire process behind GPUP and were put forward as that of environmental quality and safety, balance, sense of place, permeability, increased public-ness, integration, generosity and reinforcement (van Papendorp, 2010a). These were major points in what the City was 'selling', however, the public outcry suggests disappointment and scepticism of the actual incorporation and materialisation of these.

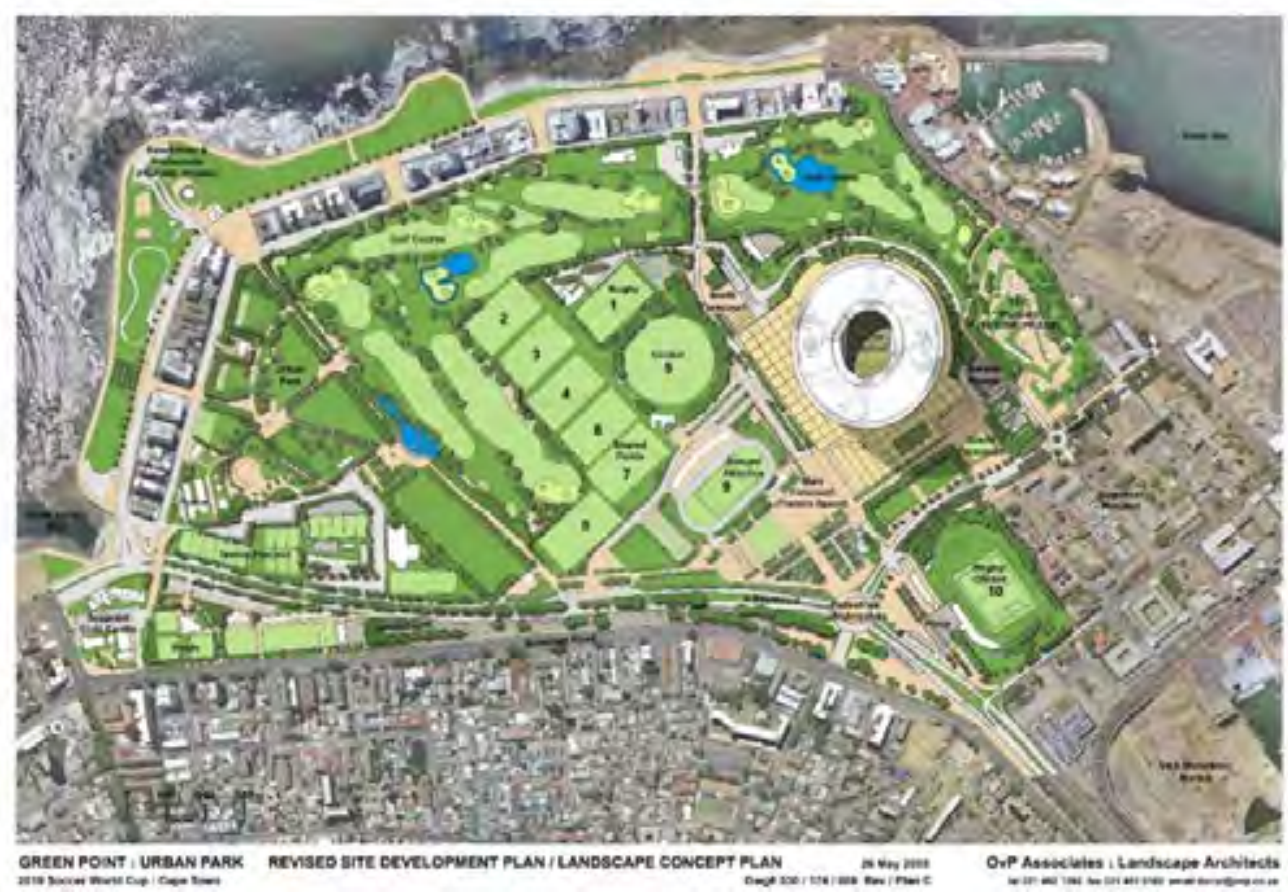

Figure 8: The approved Concept Plan for GPUP (van Heerden, 2012)

The process behind Green Point Park also encompassed a combination of the City's wider ideals, world class aspirations, sustainability and green goals and vision for safe and accessible public open space. The vision of the park was also underpinned in the final ROD, where it was to become the 'critical public/social space element' in the south-west section of the larger urban park precinct with a particular emphasis on recreation, education and social interaction (van Heerden, 2009). It was envisioned to become a three-fold 'people's park': designed to be an urban park, an inclusive park and an educational park (JVP, interview: 28 September 2015). Just as the urban park, it was to become a multi-purpose park of both local and metropolitan significance to serve as a public resource to all. This includes the local community in an 'immediate', direct sense and the wider metropolitan community in a 'broader', indirect sense (van Papendorp, 2010b). 
"The Green Point Common should become a living park, vibrant, busy and safe: a great inner city park such as those found in most cities of the world and one that serves the everyday recreation needs of the people within the city" (van Heerden, 2009).

This aspect is also in 'exception' to other city parks. The highest category used by City Parks are so called 'district parks', and are mostly located in historically privileged areas. This park, in its connection to a neoliberal endeavour and wider 'urban park' legacy, was stretched in its purpose to appeal to a wider urban public and become Cape Town's signature park in its own right. This is a trend in many international, cities that have such a park to contribute to the city's brand (DG, interview: 4 July 2016). Part of what the park's vision was also a very particular green and sustainable, or "natural draw" (Figure 9). This was informed by the surrounding natural environment and inspired by some international urban parks (JVP, interview: 28 September 2015; DG, interview: 4 July 2016). In our interview, the landscape designer explains that the park was envisioned to be a "green landscape". This is in correlation to the 'Greening the City' initiative and long-term sustainability goals, while also fulfilling the 'dream' of the City since the 1980s to develop a linked open space system from the city centre to the beach front (JVP, interview: 28 September 2015).

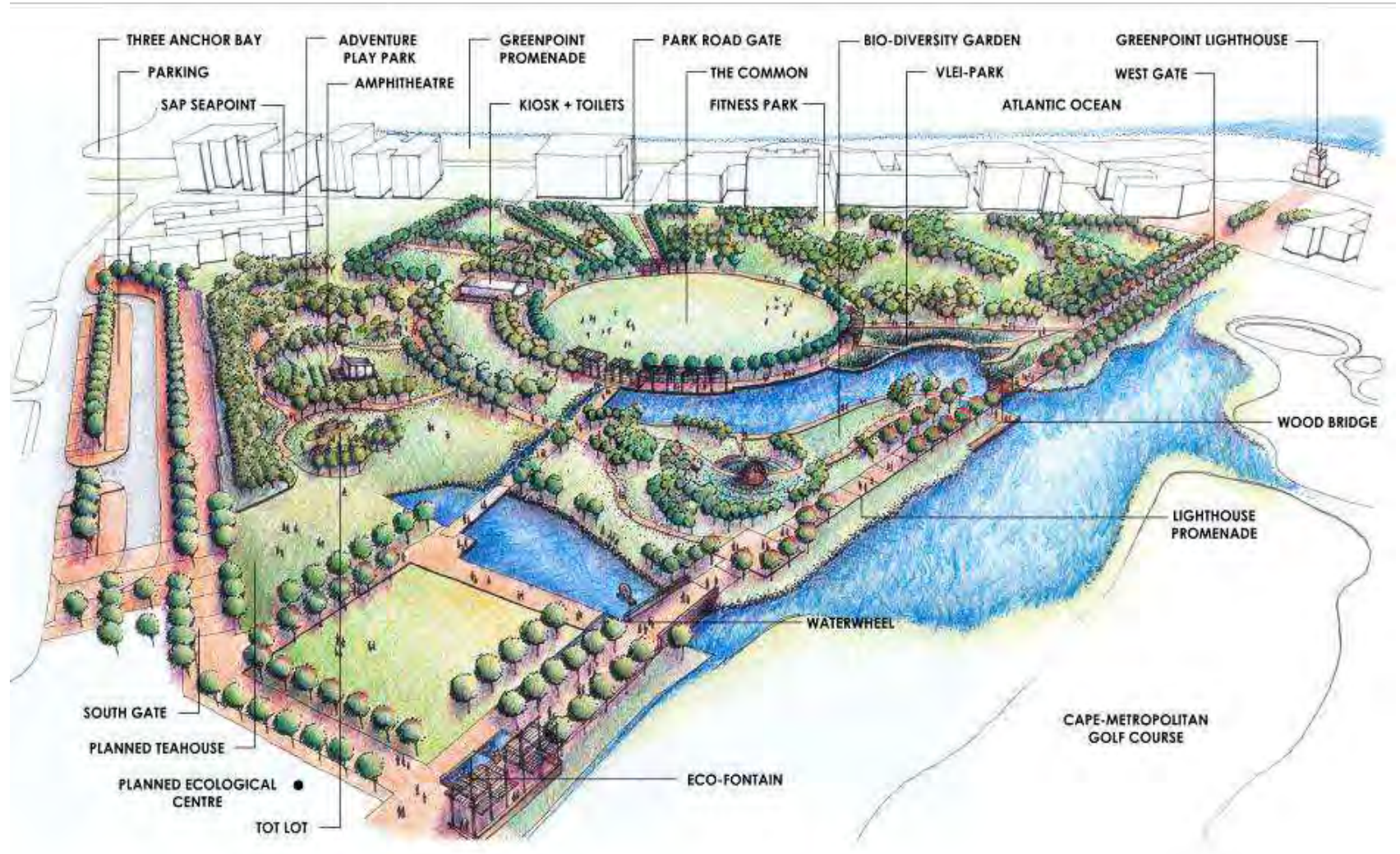

Figure 9: The Green Point Park design (van Papendorp, 2010c) 
The planning director ascribes the success of the park to the fact that it was "fantastically contextualised" (PVH, interview: 23 February 2016). In addition to the physical design, the planning also considered how the park was best to function. An important objective, by way of example, was to maximise public access while safeguarding the park's valuable contents. The landscape designer explained a trade-off between maximising entry and security, whereby they decided on four main entry points to each side of the park, but with the condition of them being locked at night and patrolled by security guards (JVP, interview: 28 September 2015). Ultimately, in working with this international, environmental quality and safety mind-set, the park was particularly planned to become a multi-purpose park in which all citizens of Cape Town could somehow be recognised as a user.

In this 'exceptional' vision from 'Common to park', the paradoxical notions of a safe and regulated, yet inclusive and accessible park take shape. In the next chapter I expand on how this translated to the park on the ground. The management became the product of a binding ROD, overarching parks and public space policies, demands of rate-paying citizens, as well as the specific hands-on modus operandi 'in the park'. This places the expensive, highly regulated and pretty public park, and the whole precinct that it is connected to, as an "anomaly" and 'exception' in the city (DG, interview: 4 July 2016; DM, interview: 28 June 2016).

\section{Conclusion}

In this chapter, I trace what started as a turbulent time in the planning and transformation of the Green Point Common into a world-class aspiring public park. This was encouraged by the City's neoliberal incentive of hosting a World Cup while also having to secure a long lasting 'legacy' for its citizens. I first consider the City's bartering with public space in an already privileged area, as an 'exception' for how other parks are provided for. I then explore some of the ways in which the planning transpired by 'exception' through a somewhat exclusive process of experts, a strong public 'fight', concern for the historic Common and disappointment in the extent of public involvement. Lastly, I present the change in vision for the Common that had to be 'sold' as a worth-while park. It became an 'exception' in its larger urban intent and vision of a safe, regulated, yet accessible, sustainable and world-class park. This chapter on the park's conflictual planning 'by exception' seemingly resonates a debate on the demise of 'truly' public space and commons. While this South African city's neoliberal endeavour did implicate the 'loss' of a historic Common, the thesis later suggests an opposite and paradoxical narrative. 


\section{Chapter Five}

\section{The Park in Practice: Managing a Place of 'Exception'}

\section{Introduction}

In addition to the park's planning 'by exception', I could observe a 'park in practice' that is also operated 'by exception'. As I spent my time in the park, interacting with park users, taking notes and talking with different 'actors', I found there was much to see and do and much behind what keeps that going. This chapter adopts a different tone as I explore dynamics within the park itself, recorded during fieldwork. I unpack the 'park in practice' in terms of its everyday operation, management and regulation that maintain the vision of a safe, clean, and pristine park. I consider how the City now runs this park successfully through a unique and somewhat improvised management vehicle on the ground, and in 'exception' to how it generally works for other parks. The park displays a mixture of both 'neoliberal' and 'public' management mechanisms, carried out by a number of hard-working 'actors' with a real dedication for nurturing the park.

\section{A Walk in the Park}

With each park visit, I faced the pleasant challenge of deciding where to go and what to do. The park user is spoiled for choice with a plethora of park features suitable for passive and active recreation, events, jogging, cycling, walking dogs, exercising etc. (PVH, interview: 23 February 2016). This thesis did not take the aim of unpacking the actual park use or park users, however, it was clear from observation that there is no single park use or park user. Five years after opening, the vision of a 'multi-purpose' 'people's park' has materialised. As the planning director insists: "the park was not intended to be a pretty English garden" (PVH, interview: 23 February 2016). Below follows a descriptive tour of the park to provide some context.

The landscape architect explains that the park was designed around the Green Point Lighthouse as focal point, with paved and unpaved pathways connecting to the different zones of use. Owing to the coastal location, its "landscape character" was also determined by a harsh environment and had to accommodate difficult physical conditions such as strong Northwesterly and South-easterly winds and a tricky soil profile (JVP, interview: 28 September 2015). There are four 'gateways', open only between sunrise and sunset. The West Gate leads towards the lighthouse and the East Gate connects to the Fan Walk and stadium. The main South Gate has a large parking lot, and the smaller Park Road gateway leads to the adjacent 
apartment blocks and beach front (JVP, interview: 28 September 2015). In the parking lot, informal vendors sometimes sell ice-cream and snacks to the delight of park users. In the centre, the park expands outwards from the 'round lawn' or 'common', where users are free to be creative in use. Here, young and old enjoy some sport, a picnic, or stroll with the dog.

\section{Field notes, Sunday April 17, 2016 (11:45-12:45)}

A young woman and her children are sitting underneath a half moon beach tent. At the picnic benches, one family has draped a red blanket on the wooden frame to mark their chosen picnic spot. Others are playing with a Frisbee on the lawn. A group of young boys are playing cricket with a plastic ball, bat and wooden stumps.

Along the paved boundary of the round lawn, three sets of wooden 'pergola' structures with benches and tables have been erected for shaded seating and picnicking (RM, transect walk: 15 April 2016). This is the prime spot on any weekend, where families lay out a colourful display of tablecloths, food and drinks (Figure 10).

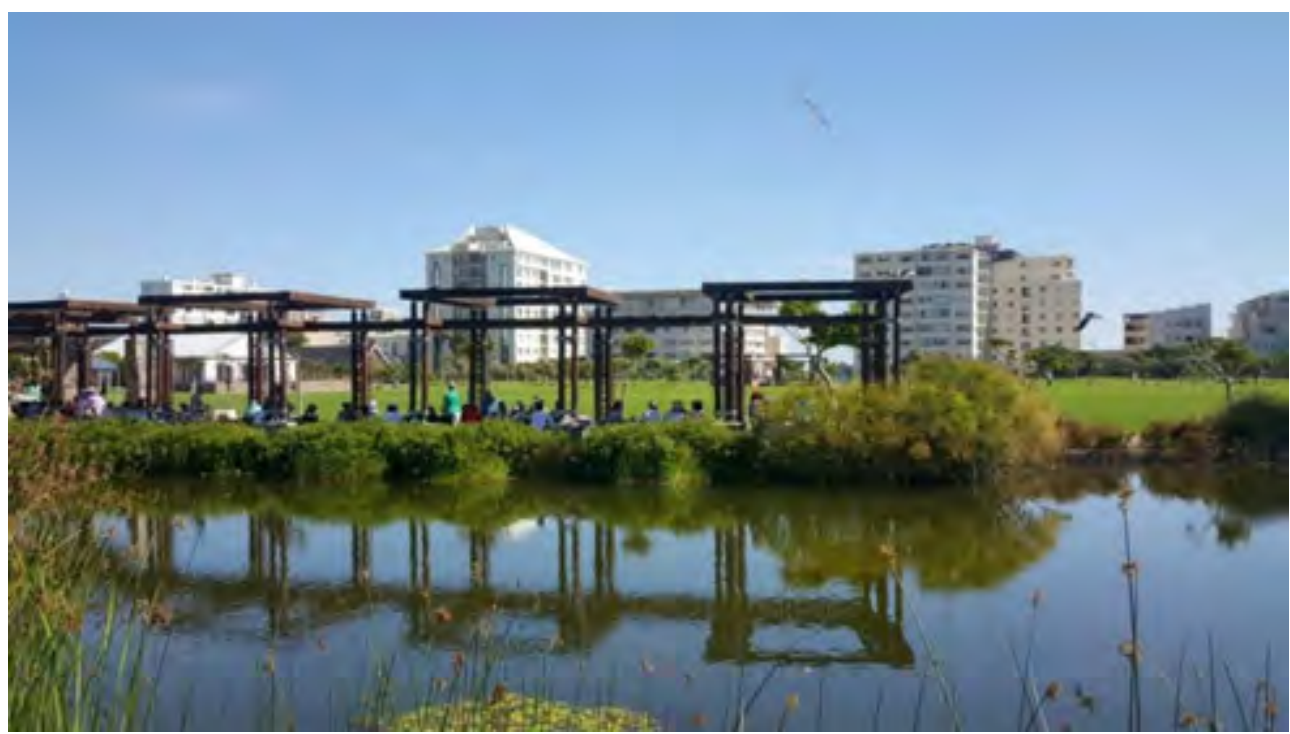

Figure 10: A typical picnic scene in the park

In the southern section, two play parks form one of the busiest parts of the park, since at least $40 \%$ of the park users are children. The 'toddlers play area', or 'tot lot', accommodates children aged one to six, while the 'adventure playground' is for older children between six and twelve (RM, transect walk: 15 April 2016). Large groups of pre-schoolers and primary school children, under the supervision of care takers and teachers, often enjoy the play equipment. Between these play parks, sits a beautiful wooden amphitheatre with tiered lawns for seating purposes. It has been used for concerts and events by the local community (RM, transect walk: 15 April 2016). An outdoor 'fitness park', or 'green gym circuit', is an extension of the play parks for persons older than the age of 12 and hosts a series of bright, yellow and blue, equipment with instruction plates (RM, transect walk: 15 April 2016). 
Field notes, Monday April 18, 2016 (10:45-13:00)

I walk to the fitness park and approach a middle-aged lady. She came with her son who is doing sit-ups. He comes four to five times a week for training. She really likes the fresh air while her son maintains that "wow a lot of things come to mind". He likes that it is well maintained, that there are so many people looking after the park, and that everyone is so friendly. "It is very cool to work out here!".

Ablutions are also provided. An empty building stands next to it, but was originally envisioned to become a kiosk or café. (RM, interview: 8 October 2016). Adjacent is a wild growth area, scattered trees and a 'walk-on analemmatic sundial'. In the western corner, a labyrinth is shaped by low-growing plants. Benches have been placed along the pavement with plates on each side to serve as 'finger labyrinths'. These parts of the park were specifically designed to be inclusive of disabled persons (RM, transect walk: 15 April 2016). An important structural element, the 'lighthouse promenade', is the walkway that connects the eastern and western gateway. A wooden bridge crosses over the lake, shared by the park and the golf course. Along the promenade, benches have been placed looking out onto the golf course and lake. Another wooden 'pergola structure' close to the East Gate looks out on an 'eco-fountain'. Joggers, cyclists, dog walkers and avid photographers typically use this walkway. Every Saturday morning at 8 am, the park also hosts the Green Point Parkrun (Figure 11).

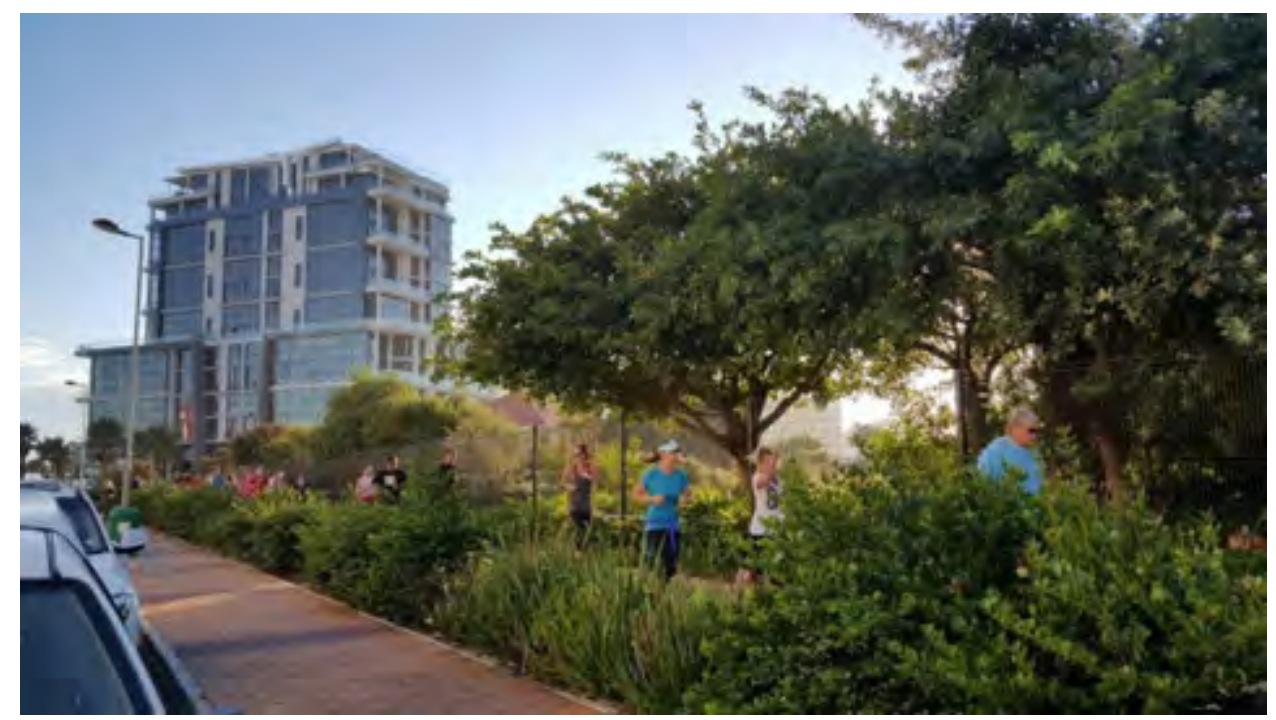

Figure 11: The Saturday Green Point Parkrun

Field notes, Thursday April 14, 2016 (11:45-13:45)

I talk to two married pensioners on the bridge. They are from Port Elizabeth and came across the park by accident when they visited the lighthouse. They were pleasantly surprised, assuming it would be like any other run down park, but saw something "green, open and interesting". They are impressed by the kids play area and different age groupings, the natural equipment, the maintenance, the signage, and the impressive biodiversity and educational garden. Also, that it is free and child-friendly in a touristy part of Cape Town. 
Another beautiful feature is the 'biodiversity showcase garden' and 'wetland walk garden' with lookout decks that host a range of indigenous flora and fauna and are decorated with artworks made of beads, steel and other material (RM, transect walk: 15 April 2016). This includes a green dome and 'people and plants' exhibition (Figure 12). Throughout the park, the user is treated with informative 'storyboards' and other signage to communicate important information and interesting, educational knowledge relating to that particular area. "It was sort of to make a story" (JVP, interview: 28 September 2015). Other features include the upper lake that hosts a big waterwheel and 'stepping stone bridge'. The lake by the golf course acts as a barrier to minimize fencing. Eight sets of drinking fountains are also to the convenience of park users and their furry pets. In the southern border, close to the ablutions, the worker's quarters include offices, storage rooms, bathrooms and showers. This is where the bins, lawn mowers and other maintenance equipment are stored and where the 'actors' in the park come together (RM, transect walk: 15 April 2016).

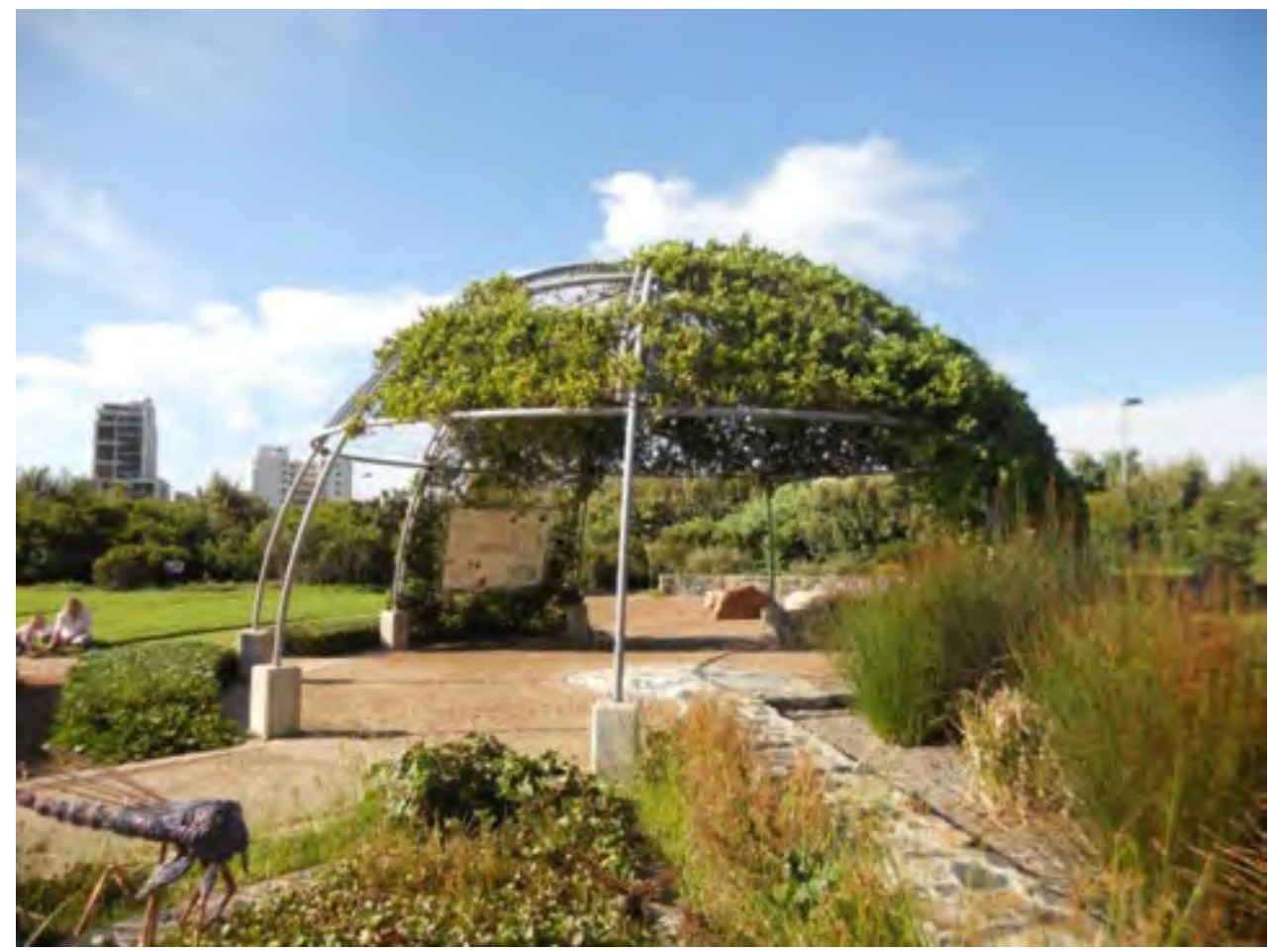

Figure 12: The dome in the biodiversity showcase garden

Field notes, Sunday April 17, 2016 (11:45-12:45)

I stand by the benches overlooking the golf course and approach an elderly man. He is from Cape Town and comes here every day to walk through the park and appreciate the beautiful surrounds, mountains and the serenity. He enjoys the setup, the greenery and praises the work of the horticultural guys. 
While the park can ascribe its origins to the financial and political opportunity of a South African city's once disputed neoliberal and global endeavour, this space manifests today as much more than just the fulfilled promise and pretty 'legacy' of a sporting spectacle that occurred six years ago. Today, the 'exception' lies also in the 'park in practice'. What keeps this park running as a success daily, takes the shape of intense 'nurturing' and a paradoxical mix of 'public' and neoliberal management mechanisms. Part of the heartbeat of the park is the host of friendly field staff that are there every day. Security guards, landscapers, cleaners, maintenance workers, supervisors, managers and other temporary workers are as much part of park as the beautiful features and diverse park users. A big team of around 50 'actors' nurture this well-used public space (RM, interview: 8 October 2015). This aspect is an 'exception' in the city as most don't have such a large and dedicated workforce. There are however, for some of the larger parks, with special characteristics, individual facilities managers. Generally, one facilities manager would oversee a large group of smaller parks in a particular district (DG, interview: 4 July 2016).

\section{Up and Running: Managing a Place of 'Exception'}

This park's neoliberal beginnings and planning by 'exception' would afford it its 'exceptional' management position today. In this section, I unpack how this extends to its daily nurturing.

The park facilities manager usefully describes this management position by sharing that "the site is an island", effectively "divorced from other City programmes". There is no precedent to which they operate. I describe the 'park in practice' as a paradoxical mix, where 'public' and neoliberal visions and mechanisms interplay. While it is officially run by the City and financed publicly, it is not managed by City Parks as is typically the case, and also receives a high maintenance budget (RM, interview: 8 October 2015; DG, interview: 4 July 2016). This can be traced back to the initial plans of the City. Prior to the World Cup, the SAIL Group and Stade de France Consortium were awarded the tender, as operators of the Cape Town Stadium and GPP in 2009, to last until just after the event (City of Cape Town, 2012). The private operator was to enter into a long-term lease agreement where after they would still manage them and share the income with the City. This never materialised due to various legal, administrative and financial viability issues. The City itself, and the experts already involved with the precinct, eventually took over the management at the start of 2011 (City of Cape Town, 2012). Today, the park is informed by the interplaying ideologies of a binding ROD, 
overarching parks and public space policies of the City, demands of its rate-paying citizens, as well as some particular hands-on modus operandi (RM, transect walk: 15 April 2016).

On the one hand, the park itself emanates a strong neoliberal undertone. This is evident first in its location in a stunning part of Cape Town. Secondly, the park looks elite and exclusive. It is always well-kept and boasts a host of valuable features and 'green' image. Thirdly, the park is a costly operation, employing a big team of 'actors' both internally, and from the outsourced services of private companies. Interestingly, City Parks itself also makes extensive use of outsourcing, particularly for specialised work (DG, interview: 4 July 2016). Furthermore, the park is tightly regulated with a strong focus on safety, it reserves the right of admission, has CCTV cameras at the entrances; and a number of security guards patrol the park while taking note of people as they enter (RM, transect walk: 15 April 2016). This focus on safety is not exclusive either. A hand full others that are managed by City Parks, such as in Maynardville and Khayelitsha, are also protected by security guards. A lack of enforcement capacity and preferred "eyes on the park" approach are reasons behind this (DG, interview: 4 July 2016).

Yet, on the other hand, the park is also an accessible and inclusive, 'public' park. Firstly, the park is free. This is just one of many stipulations in the City's by-laws that Green Point Park must comply to (City of Cape Town, 2010). These determine the rules for and within all parks (RM, transect walk: 15 April 2016). It is also funded publicly. For some other parks in the city however, external and private funding has become necessary due to little financial resources and sometimes takes the shape of 'Friends of the Park' groups (DG, interview: 4 July 2016. The only private contribution here can be linked to the sponsoring of the labyrinth during production (RM, transect walk: 15 April 2016). Secondly, the park remains 'public' in that it continually strives towards inclusiveness in its design and use. Lastly, and perhaps most significantly, the 'publicness' is displayed in the dedication of its 'actors' that nurture the park into one that is safe, clean and pristine and resultantly attractive for all. At any time of the week, the curious observer can notice them wearing their respective uniforms and name tags engaging in a particular activity. There are cleaners washing the windows, sweeping the floors or stocking toilet paper. Security guards watching over park, taking notes on their clipboards and communicating via 'walkie talkie' transceiver or helping a visitor while maintenance workers do the repairs. There are also landscapers plucking out unwanted weeds, pushing wheelbarrows, pruning trees or raking leaves. The pro-active manager and supervisors are there regularly, instructing the 'actors' on a particular task or driving in golf carts doing inspections. In addition to these primary tasks, the 'actors' personify a vital part of the park ethos which is 
to be friendly 'brand ambassadors' of the City for any park user to approach (RM, transect walk: 15 April 2016). On many occasions, I came across a friendly security guard, cleaner or landscaper that have paused their work to engage in casual conversation with a curious park user. This is another 'exception' to the city's parks as the workforce are not typically tasked with this additional responsibility. The park exudes an inviting atmosphere in what the park manager calls a "living space". This links to some previous discussion on how this park is 'sold' daily (RM, interview: 8 October 2015; DG, interview: 4 July 2016).

There are however difficulties in balancing the neoliberal 'legacy' with a resource intended to be of a purely 'public' nature. The manager explains that these unique factors determine their everyday management but are advantageous and disadvantageous at the same time. By way of example, while Green Point Park receives special attention for a park in the city, there is difficulty in dealing with the private sector and temporarily contracted employees that aren't always invested to the greatest degree and that might lack necessary skills. These 'actors' aren't there for long enough periods either. Also, managing the demands and needs of a very diverse and heterogeneous public can also be challenging, creating issues such as a range of complaints and racial conflict that must be managed (RM, transect walk: 15 April 2016).

In my time spent in the park, I could appreciate that this is not an easy park to run. It is one of the most popular attractions in Cape Town, with an estimated minimum average of 700000 visitors per year (RM, transect walk: 15 April 2016). Maintenance is a large effort by varying 'actors' performing specific tasks as the day demands. I am fascinated by 'the park in practise', the story told by its 'actors' that goes deeper than a pretty appearance and favourable use. These 'actors' work towards a park that they, as well as the public, can be proud of.

\section{Field notes, Wednesday April 13, 2016 (11:00-12:30)}

I spoke to a 45-year old male landscaper working in the biodiversity garden. When I asked him about interactions with park visitors, he said communication is very much part of his job. He can't even count how many people he has talked to today! He must always give them attention and leave whatever he is busy with. He explains that the locals always want to know something.

But what determines the modus operandi of the park? The manager usefully explains that everything that happens 'in the park' is in alignment with three very important principles. These management priorities are also in alignment with the City's by-laws as they pertain to all parks and are subject to auditing (DG, interview: 4 July 2016). Green Point Park strives every day towards; (1) the safety and security of its park users, (2) health and cleanliness, as well as (3) technical design and upkeep (RM, interview: 8 October 2015). These are the non-negotiable 
qualities ensuring that it stays an ideally safe, clean and pristine park and may vary depending on particular zones of use. The management places a lot of investment into the working 'actors' of the park. For the proper execution of individual duties, they are also offered specific types of training. All employees, for example, receive brand ambassador training. The security guards work by way of drafted manuals as well as initial training. The horticultural crew receive more specialised, continual training, while the cleaners do not receive any additional training. This could once again be placed as an 'exception' (RM, transect walk: 15 April 2016; DG, interview: 4 July 2016).

The first and most important priority is for the park to be safe and secure. This correlates strongly with its neoliberal ties and the City's larger vision and policies towards a 'safe city'. From my personal research experience as a female, this was a tremendous relief. Safety is viewed both in terms of physical security and the safe use of the park and quality of the facilities. Safeguarding the park's huge monetary investment is also part of this (RM, interview: 8 October 2015). Various safety checks are conducted, such as daily checks on equipment and monthly water quality tests. Furthermore, the park is completely fenced and CCTV cameras are in place at all four access points that are also locked after dark and open only at sunrise (RM, transect walk: 15 April 2016). The 'actors' enforcing this priority, are the security guards, privately employed by Smada Protection Services. The manager explains that there are between fifteen and twenty female and male security guards that are either stationed at the entrances, other points in the park or that are patrolling the grounds. The job entails both 'straight day' and 'straight night' shifts, meaning that the park is always secured. There are more security guards over the weekends, while less are necessary during weekdays and night shifts. A fixed schedule is set up beforehand, which entails a so called 'deployment spec'. Each worker is assigned with a specified area and work description (RM, transect walk: 15 April 2016). Some security guards watch over cars, for example, while others make counts of people entering (Figure 13).

\section{Field notes, Wednesday April 20, 2016 (13:15-14:15)}

I spoke to a young female security guard sitting by the outdoor gym. She explains that they have different roles in the park. She is currently stationed at the "adult play area". Her job is to make sure that the people using it are old enough. She is also making counts of people entering by Park Road. She shows me the form and the counts with different categories. She explains that it is challenging when she must manage the people...she mustn't shout but just explain what they are doing wrong. She insists "there is no stress here". A man later enters the park and she stops to make his count. 
Field notes, Monday April 11, 2016 (12:30-14:00)

I approached a young female security guard sitting at the West entrance. She started work last year and must simply make sure that people are "safe and happy". She is currently in charge of the gate and shares a scenario: if there is a threat she must communicate with the people at the other gates. Very coincidentally, the guard at the East gate called over the 'walky talky', and asked for her to meet him. She had to leave right away.

"They are probably the most important part of the crew...they are super important", the manager admits. They have the most challenging task of balancing compliance to park rules, keeping the park safe, “doing the job of signage that isn't there because this would clutter the park", and of course being friendly at the same time (RM, interview: 8 October 2015). There is a set list of rules that must be enforced. For example, dogs must be leashed, people must clean after pets, children under 16 must be accompanied, no 'dangerous equipment' like knives, explosives, firearms, fireworks; no fires, braais or gas, no loud music, no alcohol, no camping, no swimming, hawking, picking flowers, littering, no large structures like castles or gazebos may be erected, no ball sports that use hard balls etc. (City of Cape Town, n.d.). In addition, guards carry clipboards to record the counts of park users by category and time such as age group, gender and physical ability. The manager explains that this counting also keeps them busy during the day. These papers are then submitted at the end of each day where they are later analysed. There is no real way for City Parks on the other hand to count use for the over 3500 parks in the rest of the city (DG, interview: 4 July 2016). Yet, even with the large capacity of guards, the manager shares that there is still a need to improve as they are sometimes not equipped to deal with difficult dynamics in the park. In an example, they had to employ 'undercover operations' in the past to deal with well-dressed and communicative individuals who were actually part of syndicates (RM, transect walk: 15 April 2016). 


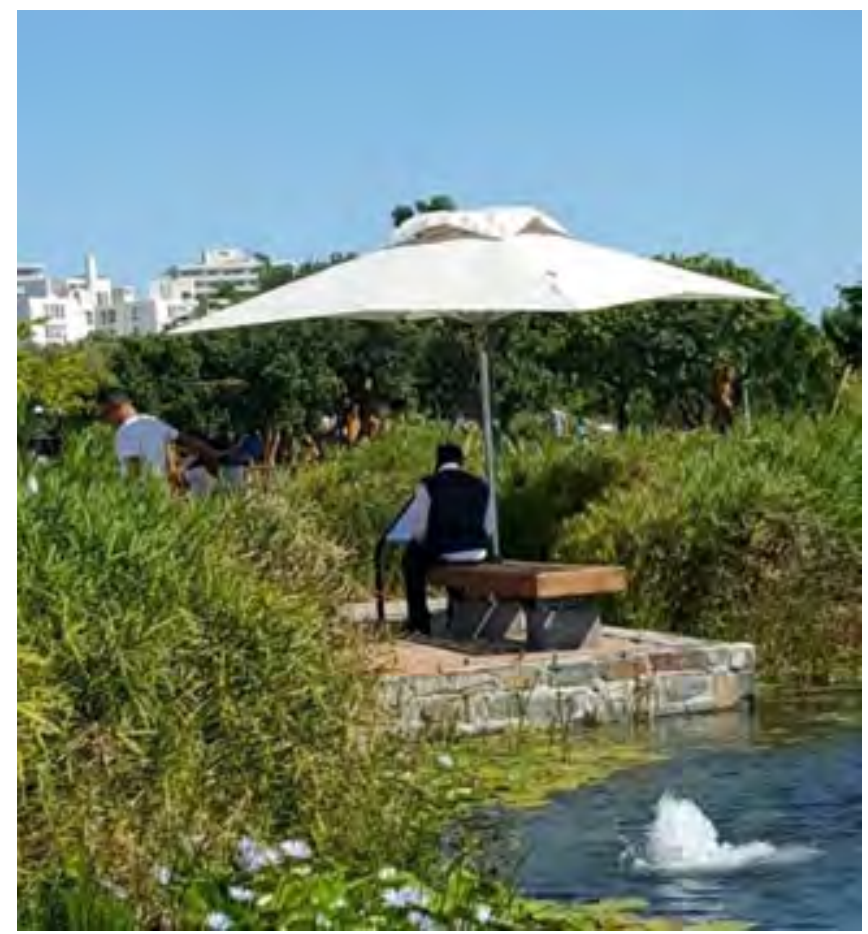

Figure 13: A security guard sits in the shade by the lake

These 'actors' must manage a lot to keep the park the safe one that it is. This is especially commendable during busy weekends and holidays when Green Point Park is packed with hundreds of users. Part of the challenge are difficult park users that contravene the rules. Some common examples are that of alcohol consumption or swimming in the water. In the case of contravention, a certain chain of command is followed. If the particular security guard cannot control the situation themselves, they first call their specific supervisor, the manager, and then law enforcement if necessary (RM, transect walk: 15 April 2016).

Field notes, Tuesday February 9, 2016 (14:00-14:30)

A middle-aged female security guard was sitting at the West entrance. She was quite apprehensive to speak to me and was laughing, looking very confused...She did say that while the job is challenging she is happy because, as a woman, it keeps her strong. She enjoys working with other guards in the park to keep her company. A challenge for her is working with the people. She must be happy even if they are difficult and treat her badly. There are no real problems, it's just that "sometimes people don't listen".

None of my interviews suggest a major security threat to constantly avert, or dangerous park user to always be on the lookout for. I was pleasantly surprised by the subtle way in which the park is kept safe by the security guards. Instead of using their power in an aggressive or invasive way, I have seen these 'actors' maintain safety by merely being present to manage each situation or risk as it arises. I observed on multiple occasions, and even conversed, with persons that one might describe as 'vagrants', homeless or extremely poor. On weekends, especially, I 
noticed vagrants trying to make tips from watching the cars which they are not permitted to do. Others were in the park keeping themselves busy. The guards never took any kind of immediate force. On one occasion, I saw a man with torn and raggedy clothes carrying all of his possessions, just strolling through the park while talking to himself out loud (Field note: 14 April 2016). In another encounter, I spoke to a poor middle-aged lady standing alone on the grass. She was an immigrant struggling to make ends meet. She was very warm towards me, asking for the time. She was waiting in the park to "keep safe" before going to the place where she gets food and sleeps close by (Field note: 17 April 2016). Another man shared simply: "I feel safe in the park, there is security" (informal interview: 18 April 2016). The manager acknowledges that they do sometimes deal with 'vagrants' and beggars that cause problems such as theft and other illicit activities, but that the security guards have learnt how to identify and deal with these situations just as they would look out for and control any other form of contravention (RM, transect walk: 15 April 2016).

\section{Field notes, Thursday January 28, 2016 (10:00-11:00)}

Today I spoke with a young male security guard standing near the round lawn. He was extremely friendly, smiling widely. He has worked here for 2 years...they never really have to deal with any major incidences but that they do sometimes have deal with 'vagrants'. Vagrants are allowed in the park since it is a public space, but the problem is that they sometimes come to ask for food, begging. Only then they can "chase them away". He says it is not that they stay away, they do come to the park. The only other problem they sometimes have is alcohol use...they are not allowed to check the bags at the entrances but that they are allowed to check the cooler bags. This is especially problematic around the holidays and December.

\section{Field notes, Friday February 12, 2016 (14:00-15:30)}

I spoke to a young female security guard sitting by the round lawn. She loves the park. She appreciates that it is peaceful and quiet. Sometimes, it is a challenge for her to look after the children at the playpark, as they can easily get hurt. It is a challenge getting the kids to keep to the rules... "they always ask why?". There are some difficult visitors... "but you must be polite". The only real problem is the 'bergies' asking for money in the carpark. In terms of vagrants, she explains they do follow them, sometimes they must chase them out...they aren't allowed to just sleep there but they can use the park, like the toilet. The problem is that they may steal from other park visitors.

The second most important priority, is to deliver a park that is clean at all times. The manager explains that cleanliness is important as they are audited on that as well. In this regard, they adhere to the strict health standards of the City. This has been an ongoing challenge for them (RM, interview: 8 October 2015). Ironically, as we were doing the transect walk, a security 
guard explained that a man was upset about the colour of the water in one of the drinking fountains and threatened to sue the park (RM, transect walk: 15 April 2016).

There are two groups of 'actors' here. There is a full-time cleaning crew employed by Bidvest Cleaning, and a horticultural crew employed by Servest Landscaping. A fixed schedule is prepared for each worker. There are around five facilities cleaners that ensure the ablution facilities and drinking fountains are cleaned several times a day. The team of around twenty horticultural workers or landscapers tidy up the other parts of the park before tea time, after which they continue with their horticultural duties. This includes cleaning the benches, raking away leaves and stones, emptying the bins and picking up papers etc. (RM, transect walk: 15 April 2016). During my park visits, I often came across cleaners around the ablution facility and adjacent building either cleaning the windows, sweeping the floors or replacing the toilet paper. In one interview, a young female cleaner explained that she likes to keep everything "nice and clean" and that she enjoys everything being "in place and proper". For her "it is important to make sure that it is spotless" because she doesn't want the park to get a bad reputation (informal interview: 13 April 2016). Over the weekends, cleaners are faced with the challenge of working amidst large groups of people swarming around the ablutions. In addition, they must manage its use. For example, making sure young children are always supervised. Furthermore, the manager admits that the cleaners work in an environment that could easily become risky. He says that: "if anything is going to go wrong, it would probably be at the toilets" (RM, transect walk: 15 April 2016).

\section{Field notes, Sunday April 10, 2016 (13:30-14:00)}

I spoke with one of the male cleaners, who was busy cleaning the men's ablution facilities. He was very busy; I could only have a few minutes. He really enjoys the work, saying "there are lots of tourists visiting this park". He cleans the drinking fountains and bathrooms two times a day. The park users are not too messy, he admits.

\section{Field notes, Monday April 18, 2016 (10:45-13:00)}

I saw a young female cleaner, cleaning with a broom and dustpan. "Its fine", she replies about her job. They must do anything to keep it "nice and spotless". She cleaned the toilets in the morning and was busy sweeping the floor. In particular, they must clean the toilets, floors, walls, mirrors, empty the bins, clean the hand dryers, doors, and hand sanitizers in the morning to "to keep it all shiny". During weekends "it's in and out the whole time", today is exceptionally quiet. 


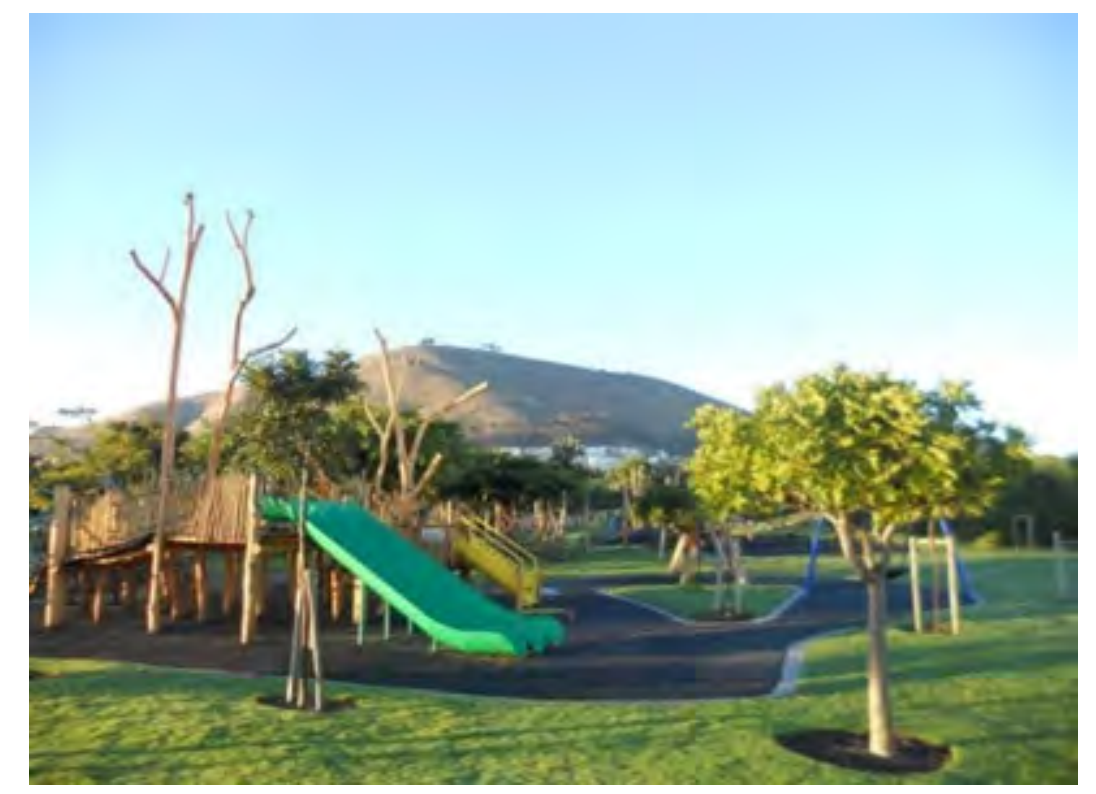

Figure 14: A 'clean and pristine' adventure playground

Lastly, the park strives to be in superior technical condition through upkeep of the original design and vision in order to keep it as pristine as possible (Figure 14). Maintaining the actual aesthetics of the park is the most difficult for them to manage (RM, interview: 8 October 2015). Not only are the coastal conditions a challenge, but so is ensuring that the facilities and features are in good order. This requires them "being ahead" in management (RM, transect walk: 15 April 2016). The manager explains that this requires more specialised skills and they often call in specialists to share their expertise with the field staff. This includes occasional maintenance workers, irrigation specialists, or refurbishing specialists. As part of the technical maintenance, the park also incorporates principles of environmental sustainability. In an example, the manager showed me where they recycled algae from the lakes to use on the soil to retain water. He shares that they are currently placing all their signage under review to upgrade and replace them. They have also recently replaced all the beadwork in the biodiversity gardens because these features are easily damaged or vandalised (RM, transect walk: 15 April 2016).

\section{Field notes, Thursday October 8, 2016 (09:30-11:00)}

The park is very quiet. There is a lot of maintenance work happening today. Workers are watering and mowing the lawns, picking up trash, and there are two men fixing the timber railings at the play park.

But perhaps the most fascinating 'actors', in my opinion, are the very passionate landscapers or 'horticultural crew', that physically bring the park and its beautiful vision to life. I thoroughly enjoyed my interviews with these 'actors' who all shared a passion and pride for what they were doing, were eager to learn more, and strived towards making the park even better. 
Field notes, Wednesday April 13, 2016 (11:00-12:30)

I spoke to a middle-aged female landscaper working in the labyrinth. She was extremely passionate, telling me "this is where I belong". When I asked whether she was satisfied, she said the park is very pretty, but it is not as good as it could be. She wants people to be in awe immediately and "feel that this is where they want to be". Her job was to prune and trim the plants that are growing into each other (she showed me a sheet of paper with her schedule for the month). "You must know how, and where and when". People shouldn't say anybody can cut a tree because there is much more skill behind it, she explains. Talking to park users is also a big part of her job. People come up to her and ask questions. She must then put a smile on her face and help them, perhaps answer their questions or show them something.

With their overalls on and garden tools in hand, these 'actors' are visible during the week and early in the day cutting grass, pruning trees and bushes or raking leaves (Figure 15). I am appreciative of their work effort and attention to detail, especially with the hot sun in the summer time. When walking through the biodiversity garden, the labyrinth, or along the lighthouse promenade to the sight of beautiful displays of greenery kept intact each day, one is left fascinated. As the park was originally envisioned to be 'green landscape', these efforts are crucial to ensure that that this is maintained. They sometimes bring the original landscaper in to share expertise and add to the knowledge gained during training (RM, transect walk: 15 April 2016). Other specialists such as tree specialists are also brought in every few weeks. They gain a very particular skill set from learning about the plants to garden tools and appropriate garden methods. I also enjoyed the active way in which these 'actors' participate in the 'park in practice'. One landscaper, for example, shared with me how he has some suggestions as to how they could improve the lawns in the biodiversity garden. He said the management is very open to listen to him (informal interview: 13 April 2016).

\section{Field notes, Monday April 11, 2016 (12:30-14:00)}

Today I spoke with a young female landscaper. She was working alone in the biodiversity gardens and was pruning the bushes. She had thick sunscreen on, it was a very hot day. Her job with the plants is to "keep them is shape". She works specifically in the biodiversity garden. They received a few hours training. She has been at the park for one week, yet, she enjoys it a lot and doesn't find it too difficult or challenging. 


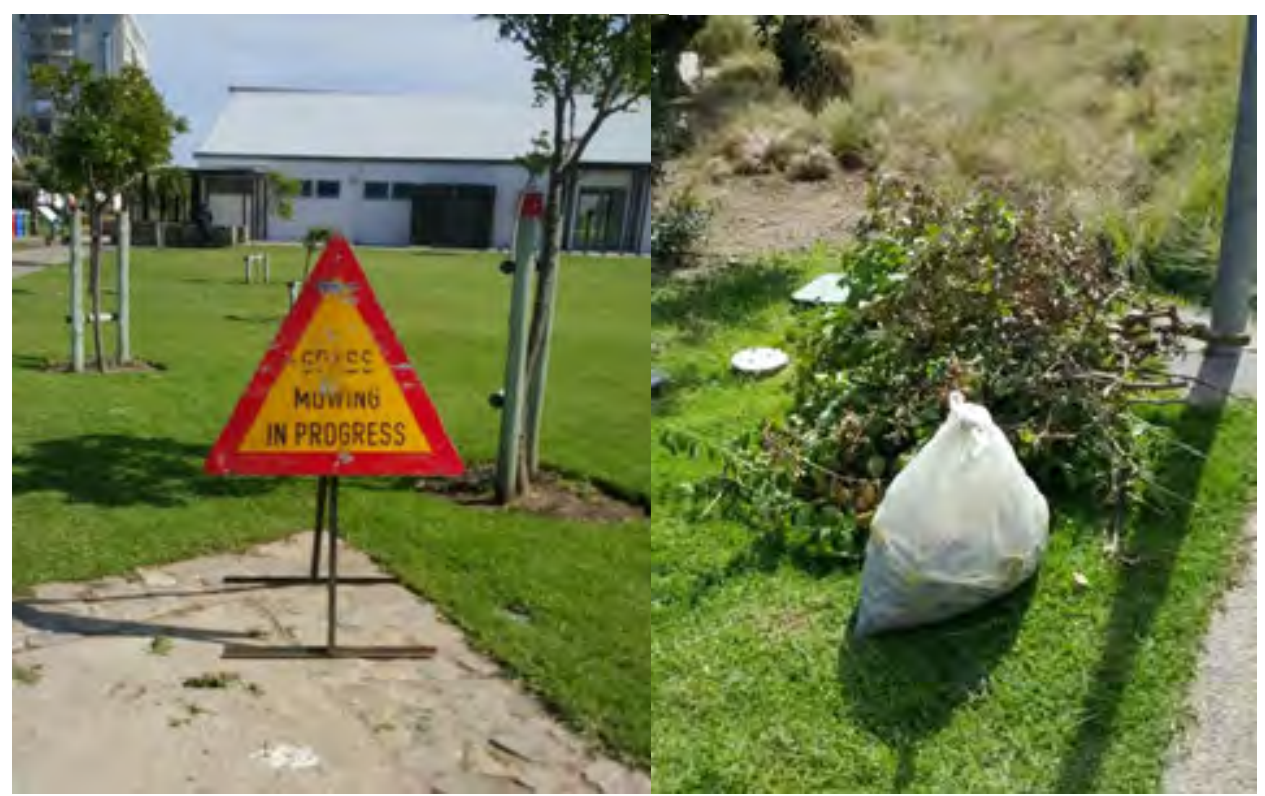

Figure 15: Maintenance operations in progress

\section{A Work in Progress}

While the beauty and adoring beneficiaries of Green Point Park would depict a successful 'park in practice', living up to an 'exceptional' vision created years ago, it is nonetheless considered by its 'actors' to be a work in progress. The manager admits "I am still not satisfied", rating them at 60\% (RM, transect walk: 15 April 2016). There exists a strong drive to go beyond the static vision on paper and take advantage of its high potential. On the one hand, a lack of funds and immediate priority to the stadium rather than the park during the construction phase has led to certain planned features failing to materialise, such as the tea room and eco-centre. But on the other hand, there is still the prospect that such original visions could come to life. One common aspiration is to host more events on a regular basis as "it would give the park a soul" (RM, interview: 8 October 2015).

The manager describes the operation of the park as "riding a wild horse", emphasizing the 'exception' and how they are constantly improvising (RM, transect walk: 15 April 2016). The pro-active way in which management is approached and the openness towards shifting ideas, as the need presents itself, is clear. They employ a very "adaptable philosophy" (RM, transect walk: 15 April 2016). This is in order to "keep redefining...keep rethinking" what makes the park work and what doesn't (RM, interview: 8 October 2015). The counts by the security guards, for example, are a personal initiative of the manager. It helps them understand how many people use the park, and the variety of people that use it in different ways at different times to accommodate specific needs. Originally, for example, the idea of allowing bicycles 
and dogs was heavily scrutinized. But today, these are among the most popular park uses. In our interview, future suggestions like free Wi-Fi or phone applications that display information digitally have been mentioned (RM, interview: 8 October 2015). 'Snap frames' at the entrances that demonstrate different zones will also be introduced. This is all in an effort to ensure that the park stays a worthy and viable investment to the City and its metropolitan public (RM, transect walk: 15 April 2016). For most other parks in the city, such options of upgrading facilities and features is not a common reality (DG, interview: 4 July 2016).

\section{Conclusion}

In the current chapter, I explore the everyday operation of a safe, clean, and pristine metropolitan park. In it, I unpack a park that is now run successfully by the City through a unique management vehicle and hard-working 'actors' that combine both 'neoliberal' and 'public' visions and mechanisms. Although this park is fully funded and run by the City and its crucial 'public' principles, it also follows a model that deviates from how other parks in the City are normally managed and maintained. In the balancing of publicness and tight regulation, however, Green Point Park can be appreciated for much more than just the expensive byproduct and forced legacy of a disputed event that ended six years ago. The finer texture of what makes the park such a success and 'exception' in the city today, can also be found in its tireless 'nurturing' and drive to improve and reimagine a 'public' park. 


\section{Chapter Six}

\section{A 'Paradox of the Commons'? In Conclusion}

\section{Introduction}

Green Point Park is a South African place of 'exception', productively balancing a city's elaborate neoliberal strategies and the role of a metropolitan 'public' park. This thesis tells the paradoxical story of a park that despite the 'legacy' of a controversial World Cup, planning 'by exception' and tight regulation, forms a magnet for diverse urban residents. This took the purpose of furthering the literary discourse on parks, public space and the commons, and their fate also in the particularly relevant post-apartheid city. The literature displays a tendency to assume that these spaces are subject to an inevitable 'end' or 'tragedy' from the destructive influence of neoliberal forms of planning and regulation. This is echoed in contemporary South African cities as contexts of perpetuated and new forms of inequality and exclusion. The current chapter forms the conclusion in which I draw the thesis together. In the first section, I conclude the empirical story of the park and its evolution from the old Common through its planning and management processes that are 'by exception' in terms of how these typically unfold, and in their productive mix. In the second section, I propose my analytical argument. I do so first by considering that despite these processes, a once sceptical and concerned public are now won over by their new, wonderfully nurtured 'public' and 'common' park. Second, I situate my thesis in conversation with a local and global literature that forecloses such an outcome. Drawing from a 'rethinking' of the urban commons, I argue that Green Point Park illustrates a 'paradox of the commons'. In this case, a neoliberally driven park that has paradoxically restored a dilapidated Common into a vibrant, inclusive city space.

\section{A Productive Mix: The City's Neoliberally Planned and Managed, 'Public' Park}

Green Point Park balances a productive mix of neoliberal and public strategies in its planning by 'exception' and tight everyday regulation and management. The narrative of 'exception' draws from terminology used by Vainer (2016), to describe the nature of these processes that have been informed by a controversial neoliberal endeavour and purpose of an accessible public 'legacy', and that also deviates from other parks in Cape Town. In this case, the 'exceptional' park is one located in a privileged area, highly expensive, tightly regulated and managed in terms of safety, cleanliness and aesthetics, and nurtured by a dedicated group of skilled and outsourced 'actors'. 
Yet, significantly, the park is 'public' in that it forms an inclusive and accessible place enjoyed by all on a daily basis. It was born from the conflictual local planning process embedded in the 2010 World Cup and the imminent change of the cherished, albeit shrinking and dilapidated Common. The park came to life through the City's desperate bartering with public space as a means of compensation for a contested mega-event that was pushed forward nonetheless. This followed the strong, local public' fight against unwanted event repercussions and a perceived 'threat' and loss of the Common that was historically allocated as public land. On board were not the City's usual resource-tight authority of City Parks. Instead a handful of specially recruited internal and external professionals, such as urban planners and landscape designers already involved with the infrastructure of the World Cup and precinct, was tasked to also deliver the public park in an already privileged part of the city. During the actual planning, the public participation process also saw difficulty in the way the City balanced public expectations on local and metropolitan levels and the non-negotiable demands and deadlines of their international clients, FIFA. While the public and I\&APs, especially those in Green Point and adjacent to the development, were involved through the opportunity to deliver inputs and attend meetings, the overwhelming feeling was an objection to the developments and concern over a lack of direct participation in the physical planning. This planning approach is not typical for parks in the city, that would generally incorporate specific local needs and requirements.

A new vision and function for the 'lost' Common was subsequently set in motion. The larger Green Point Urban Park was visualised to an 'urban scale', 'international quality' and 'multipurpose'. It was also to incorporate a 'green' and 'sustainable' agenda. This vision was set in an official manner through an ROD issued by the Minister, also giving the impression of a park that had to be 'sold', or validated by a wide audience as successful compensation for the World Cup. This completely changed the function of the unregulated and dilapidated Common, to a park held to very high standards, and with a strong focus on safety, regulation and upkeep. The City's ideals of mixing safety, accessibility, worldliness and sustainability were prioritized for this one public space that had to become a successful 'public' 'legacy'. This does not necessarily mean that these standards are not strived for with other parks. However, the costly means of enforcing the new vision and function was afforded by the huge political and financial opportunity of the mega-event.

The park was not only 'planned by 'exception', but is also managed and maintained 'by exception' on a daily basis. It is here that the productive mix becomes visible. This is with the case of a safe, clean, and pristinely nurtured metropolitan park, that the City runs successfully 
through a unique and improvised management vehicle and hard-working 'actors' that must maintain the original vision and create a popular place to draw diverse people from all over the city. The hands-on means to uphold this beautiful park is far greater than what is afforded to the city's parks in general, and is also not the responsibility of the usual authority, City Parks.

Green Point Park's planning 'by exception' has materialised favourably 'in practice' and lives up to the compensatory promise of a 'multi-purpose', 'international quality' and 'people's park'. The incredible attention to detail, effort and expense of this park is clear in a stroll through the plethora of features freely accessible for the diverse park user to choose from such as the biodiversity garden or children's play area. The productivity of this park however goes beyond its physical 'legacy' to the large and very dedicated workforce, including the park manager, supervisors, cleaners, security guards, landscapers and maintenance workers, that employ a mixture of neoliberal and public mechanisms. The way this park is managed and maintained is considered to be an 'anomaly' to other parks. This lies not necessarily in the standards or rules pertaining to this 'public' park, but the greater capacity and resource to enforce them as a result of being the City's well-financed 'legacy'. This can be found in the park's rigid regulation, the vast presence of security guards or the outsourcing of dedicated workers. Yet, this park is not the only one that makes use of outsourcing or that requires a dedicated park, or facilities' manager. Other parks do make use of these elements, but restrictions mean that this is not common. Here again, while it is the City's park, and is publicly funded, its management model deviates from how others are normally maintained.

As mentioned before, the most significant part of the park, its 'exception', and productive mix, is to be found in the working 'actors' that are as much, if not more part of the park, as its material expression. Here, the park could be appreciated for more than just the expensive and forced legacy of a contested event that ended six years ago. A safe, clean and pristine park is 'nurtured' every day by very passionate and involved individuals who carry the challenges of their respective jobs in a busy and well-used park, while also representing its 'brand' as friendly and approachable ambassadors. This park, that has to prove its viability to the City, is 'theirs' too. The drive of these 'actors' to constantly improve the park, its 'publicness' and attractiveness, is another feature that has contributed to the park's success. This relates not only to the commendable aspiration and open philosophy, but to the fact that such costly prospects are not a common reality for other parks in the city that were not direct neoliberal 'legacies'. 
The park, and its processes of planning and management 'by exception', reflect a South African city's neoliberal policies of worldliness, safety and tight regulation. Yet, the park is today the public, inclusive and accessible product of its 'exceptional' planning, vision and everyday nurturing. This mix of neoliberal and public purpose is paradoxical, and challenges the assumptions in the literature. This will be examined in the discussion below in which I conclude my argument.

\section{The Restoration of a Commons: An Inclusive, Accessible and Free Park}

The way the 'exceptional' planning and management of the park has come together today, provides the city of Cape Town with an inclusive, accessible and free 'public park'. While it balances a neoliberal drive through a disputed planning process and tight everyday management and regulation, it also embodies a successful and well-used public space that is today cherished by the metropolitan public and beyond. This includes a diversity of urban residents, rich and poor, black and white, coming from close and far. In this section, I display how the 'loss' of an old Common, to create a neoliberal 'legacy', has rather paradoxically led to its restoration. This is evident in the way that this park is favourably being used, talked about and appreciated and informs my final argument of a possible 'paradox of the commons' in conversation with the literary discourse. Here, an image is sketched of a beautiful park that is well-used, and nurtured. It is a park whereby all involved walk away as delighted, and perhaps unexpected beneficiaries. This is significant in light of the transformation of an unpleasant Common to a regulated park, inclusive of all that claim it to be 'theirs'.

When it was decided that Green Point would host the new stadium, the public became highly concerned of the implications it would have on the local area, and 'threat' to what remained of the Common. What followed was a big public 'fight' and outcry against developments that were pushed ahead and compensated for with the larger GPUP and GPP 'legacy'. Significantly, a past neoliberal dispute has essentially resolved itself with the deliverance of a park that has lived up to its promise and has even added favourably to the already privileged area. Six years after the World Cup, it would appear as though the urban public did in fact draw particular benefit from the forced, neoliberal 'legacy' that it would facilitate. By way of example, individuals that were once very sceptical now easily admit that "we all love the park" (JL, interview: 23 April 2016). In the conversations I had with several local 'actors', the current success and beauty of the park prevails instead of past recollections of a controversial beginning. The park has become so popular, that the once sceptical community has come to 
embrace a 'legacy' first unsought. Some even argue that "the park is the best thing that has happened to Green Point" (JM, interview: 23 February 2016). Also, many are now less than bothered by a previous 'lack' of participation, in that despite that "we have not really been involved in the planning of the park", "we Green Point residents all love our park...that seems to attract residents from all parts of Cape Town and surrounds" (CS, email correspondence: 29 January 2016). Also, in brief discussions with park users displayed in the previous chapter, there is a real appreciation for this park and the way it balances a regulated and safe, yet free and accessible vision. The working 'actors' are also particularly attached to what they have come to love and adore as their own park too. It is a source of pride as well as a personal recreational asset. On one occasion a female security guard told me that she loves that "the park is peaceful and quiet". She brings her children to the playpark and enjoys how children play with balloons and bicycles and with their hands and legs in the water (informal interview: 12 February 2016). On another occasion, a young male security guard expressed that he comes to the park often and that the MyCiTi bus makes it easily accessible for him (informal interview: 12 February 2016). In another interview with a cleaner, she responded reassuringly: "Of course I will come to the park, it is amazing in there!" (informal interview: 18 April 2016). Furthermore, a landscaper shared how proud he is of his job and how his wife and children were very impressed when he showed them around (informal interview: 13 April 2016). These notions are in stark contrast to the prior descriptions of a 'waste of space' and dangerous historic Common, going through a low time. In its contemporary form, I thus propose that this park embodies its own 'common', inclusive, accessible and open to all.

While the thesis did not take the aim of exploring the actual 'public' use in detail, these discoveries are instrumental in my final argument. Through the way that people use, talk about, take care of, and 'nurture' this park, I was able to discover a paradoxically 'public' park' and formulate a possible 'paradox of the commons'.

\section{A 'Paradox of the Commons'? In Conversation and 'Rethinking' the Literature}

A tangible theme of exclusion and inequality can be traced through the large and foreclosing literature on contemporary neoliberal agendas and their influence on the survival, or 'public' and 'common' nature of the city's parks. This debate extends itself to the relevant context of the post-apartheid city that is also scrutinized for a perpetuation of past spatial inequities. The outcomes of the thesis and argument is placed in conversation with the discourse and later 
considered for the possible contribution that it makes to 'rethinking' these contested notions in the context of modern South Africa.

I drew the initial rationale of the thesis from Marais (2013) and Lawson's (2007) assertion that parks mirror and reveal time-specific ideologies of cities directly. Subsequently, from the empirical case, I was able to confirm the 'mirror' or reflection of this park's neoliberally driven 'exception' in the way it was neoliberally planned and managed. This took the form of an expensive and highly regulated 'legacy', and compensation, for a once contested World Cup in a contested South African City. The thesis thus echoes the terminology used by Vainer (2016) and Harvey (2006), of a 'planning by exception' and subsequent 'governance by spectacle', in the current neoliberal city. While these notions of 'exception' reaffirmed the relevance of Green Point Park as a case study to 'test' and contribute to the debate at large, my thesis later developed a narrative in contrast to its foreclosing assumptions.

In the global literary discourse, there is a strong case that show parks, as one form of public space, have in deed suffered from a limiting or destructive neoliberal threat that determines how, and for whom, these are envisioned and managed. These agendas arguably accommodate very particular, private and economic interests, and a very particular legitimate and 'desirable' public to reduce their core 'public' essence. In the modern urban context, accessibility and inclusivity is believed to give way to a new agenda of regulation and safety. I am in conversation with the scholars that are key in this public space debate. Staeheli and Mitchell (2008), for example, postulate an 'ethic of exclusion'. Low (2006) and Low and Smith (2006) regard this now exclusive agenda as the newest kind of 'threat' to public space in private and commercial form. In the particular context of parks, Mitchell (1995) validates such an unfortunate 'public' struggle and demise in his case study of the People's Park in USA that itself became more exclusive. Low, Taplin and Scheld (2005), on the other hand, use several different parks as case studies to make an argument for the contemporary need of socially and culturally inclusive parks to replace the former park models that have moved further away from this purpose. In extension to the original and radical notion by Sorkin (1992), that public space is 'coming to an end', the literature continues with varying interpretations of how the complex and tricky phenomenon which is public space, unfolds with imminent contestation in contemporary times. While these outcomes are true in the particular cases above, my thesis suggests the need to further the assumptions that are formulated from them. 
In the context of the post-apartheid city, where practices of exclusion are deeply embedded in history, a modern-day controversy around public space that expands beyond race, also echoes the former debate in another body of local literature. It is mirrored through the variety of alternative, yet perpetually exclusionary forms of public space in neoliberal South Africa that have developed from a new focus on safety and security due to fear of increased crime. The literature on parks in South Africa, in such a context is scarce, however Marais (2013) provides an account of Johannesburg's uniquely exclusive Joubert Park, to mirror the literary concerns and validate an unequal and 'socially conservative' South Africa.

Seeing that Green Point Park formed the compensatory 'legacy' of a post-apartheid city's oncecontested World Cup, and was subsequently planned and managed 'by exception', the possibility of such a demise of 'public' space was always relevant. This ties to the discourse on mega-events, global city pursuits, and public participation, that is similarly foreclosing in the assumption that 'spectacular' city agendas restrict and limit 'public' purpose, participation and the eventual influence on urban space (Horne \& Manzenreiter, 2006; Cornwall, 2008). Yet, significantly, the narrative of the park took a paradoxical turn which helped me situate my thesis and argument at a possible contrast to the two large debates summarized above. What I observed during my research was a beautiful, albeit expensive and tightly regulated park, that is used, talked about and 'nurtured' favourably by a multitude of adoring beneficiaries. It is the actual success and welcome restoration of the Common, inevitably driven by its 'exceptional' planning and management, that became the most crucial 'public' outcome. In this case then, I could posit an outcome opposite to Sorkin's (1992) 'end' or demise of 'public' space, but perhaps its actual restoration through the City's agendas that could otherwise be rendered 'exclusive', 'neoliberal', 'private' or 'worldly'. These have loaned Green Point's historic public land its desired inclusivity and accessibility and is clear when considering how many people visit the park from all walks of life, on a daily basis.

This insight is especially relevant when considering the prior state of the historic Common. This introduces the most applicable debate and segment of the literature to this case, thesis and argument. The Common became dilapidated, unused, unsafe, and was considered a waste of space by many. What remained was a somewhat 'uncommon' Common with broken fences, glass, potholes, squatters, drug lords and prostitutes.

I found favour with a recent body of literature on 'rethinking' the urban commons that embraces the inherent complexities and dynamics of contemporary cities (Borch \& 
Kornberger, 2015). These authors assert, contrary to a debate that theorizes the fragile nature of the commons, that these could in fact be enhanced by favourable consumption. In the case of this park, that stimulated a renewed interest and use, consumption did in effect 'enhance' the old Common. This discourse provides a more accommodating outlook to the fate and evolution of the commons in the neoliberal urban context, making room for my paradoxical narrative and a possible 'rethinking of parks'. In particular, I found accordance with Jerram (2015) who criticises the literature's 'historical fantasy' with traditional commons. He poses that a quintessentially unregulated and open 'common' in favour of all is neither feasible in the past nor in the urban present. The prior state of the unregulated and open Common mirrors this argument perfectly by disproving the notion that the nature of traditional commons should necessarily be recovered in the neoliberal era. Jerram's (2015) argument also makes room for a consideration that complex city dynamics in especially the post-apartheid context, with its contested neoliberal endeavours, don't necessarily take away from the Commons. In contrast to the notions of Low and Smith (2006), the transition to a park has, in this case, not been in unfortunate expense to the Commons.

The thesis displays a productive mix in the successful materialisation of paradoxical ideals of safety and exclusion, accessibility and inclusion. These are balanced by a neoliberal and 'public' park to form the foundation of my argument. While such notions are often contrasted in the larger debates, I have observed the everyday functioning of a regulated, yet 'nurtured' urban park that affords people from all walks of life the opportunity, and willingness, to access and use a restored 'public' space. From the original vision, a very particular 'people's park narrative was employed for GPP to transform the Common into a 'legacy' for all citizens of Cape Town coming from near or far. The City interpreted the ideal of an inclusive and accessible 'people's park' as one that caters to a diversity of park users of different genders, ages, physical ability and cultural and ethnic backgrounds. Crucially, there is no assumed public like Mitchell (1995) or Low, Taplin and Scheld (2005) would perhaps suggest. Instead, it is a space inviting to a multiple urban public. This dates to when the park was first planned. It was not with the intention to exclude a particular public, but with the desperate drive to win over the concerned and sceptical public and see the World Cup through.

What remains is the 'legacy' of a 'park in practice' which balances a productive mix of a neoliberal and public agenda of 'exception'. It is indeed expensive and located in a privileged part of Cape Town. It is also afforded the necessary expensive means to keep the park to high standards of staying a safe, clean, pristine and tightly regulated park and is not the responsibility 
of the usual City authority. Yet, the park still functions 'publicly' and is funded by the City, completely free and informed by the same regulations as all other public parks in Cape Town. The incorporation of certain neoliberal measures is also justified when considering the realities of safety in contemporary South Africa, that it is an expensive monetary investment for the City, and that the Common experienced a demise precisely because of the lack thereof in recent years. The park manager makes a point that is useful here. He stated that the most discernible sign of success, is seeing a young mother comfortable and safe enough to consciously bring herself and her child to the park alone. To him, this is a practical 'exception' and would never have happened on the Common before the World Cup (RM, transect walk: 15 April 2016). The park, in its neoliberal 'exception', thus informs a paradoxical addition to the literary discourse.

In conclusion, this thesis argues that the historic public space in Green Point has paradoxically transitioned from an unpleasant, dangerous and derelict Common to a well-used and accessible public-privately managed 'park'. In this form, I propose that this park is a 'common', accessible and open in its safety and regulation that includes all, to resemble a possible 'paradox of the commons'. This sits in contrast with a foreclosing local and global debate that assumes neoliberal forms of regulation and planning by 'exception' to be limiting or destructive, resulting in 'tragedy' or 'coming to an end' of the commons and public space. The 'paradox of the commons' lies in the fact that a highly expensive and tightly regulated urban park, has in its 'exception', restored the old Common's 'publicness' or 'commonness'. The park manifests today as a space perhaps more inclusive and accessible than it ever was before.

Ultimately, what does the 'paradox of the commons' implicate for literary understandings of parks, public space and the commons in the setting of the contested post-apartheid city? Simply, it provides a small, yet valuable and context-specific, testament of the need to 'rethink', or at least keep flexible and further what exists as restrictive and foreclosing understandings in the contested contemporary era. It allows a 'rethinking' of parks that could perhaps manifest productively as modern forms of public space and the commons, despite the neoliberal mirrors that they have become. In the case of this park, a neoliberal and worldly city agenda of regulation and 'exception', afforded the park its 'public' and 'common' manifestation in light of the restoration of a common. This may be the case for other parks too. It furthers a simple 'end' or 'tragedy', in the conceptualisation of how these unfold today. Most especially, this paradoxical park provides an alternative and useful lens into parks, public space and the commons in post-apartheid cities that are indeed stricken by crime and safetyconsciousness, where perhaps regulation and strict 'nurturing' becomes necessary. 


\section{Conclusion}

A 'paradox of the commons', Green Point Park is produced through a planning and everyday management process 'by exception', to successfully balance a productive mix of neoliberal and public mechanisms. This contributes to the debate on parks, public space and the commons as they have changed in their purpose and unfold as products of contemporary city agendas in the turn to neoliberalism. In this case, the Green Point Common, formerly in a state of neglect and disrepair, and a largely unused and unsafe wasteland, has been transformed into a 'public' park. It is now a nurtured, and highly regulated, park that in its quality of environment, safety and inclusivity, has restored this part of the city to make it accessible to the broad Cape Town public once again. In conclusion, Green Point Park is much more than a neoliberal by-product and forced 'legacy' of the long completed 2010 World Cup. In its success, it contributes to a 'rethinking' of parks, public space and the commons in the South African urban context. Neither an 'end' or 'tragedy', this remaking of a commons challenges literary assumptions about destructive neoliberal restructuring of cities and their diminishing public spaces, as well as the role and regulation of parks in the modern and post-apartheid South African city. 


\section{List of References}

Andranovich, G., Burbank, M.J. \& Heying, C.H. 2001. Olympic Cities: Lessons Learned from Mega-Event Politics. Journal of Urban Affairs, 23(2): 113-131.

Bancroft, K.H. 2012. Zones of Exclusion: Urban Spatial Policies, Social Justice, and Social Services. Journal of Sociology and Social Welfare, 39(3): 63-84.

Bénit-Gbaffou, C. 2008. Unbundled security services and urban fragmentation in postapartheid Johannesburg. Geoforum, 39: 1933-1950.

Bergamaschi, M., Castrignanò, M. \& De Rubertis, P. 2014. The homeless and public space: urban policy and exclusion in Bologna. Revue Interventions économiques, 51: 1-18.

Bickford-Smith, V., van Heyningen, E. \& Worden, N. 1999. Cape Town in the twentieth century: An illustrated social history. Claremont: David Philip Publishers.

Bollier, D. 2015. Reinventing Law for the Commons. Available:

http://bollier.org/sites/default/files/misc-fileupload/files/Reinventing\%20Law\%20for\%20the \%20Commons $\% 20$ memo.pdf [2016, May 15].

Borch, C \& Kornberger, M. Eds. 2015. Urban Commons: Rethinking the City. New York: Routledge.

Brenner, N. \& Theodor, N. 2002. Cities and the Geographies of "Actually Existing Liberalism". Antipode, 34(3): 349-379.

Bruun, M.H. 2015. Communities and the commons: Open access and community ownership of the urban commons. In Urban Commons: Rethinking the City. C. Borch \& $\mathrm{M}$. Kornberger. Eds. New York: Routledge. 153-170.

Chain, D. \& Swart, K. 2010. Resident's Perception of the 2010 FIFA World Cup: A Case Study of a Suburb in Cape Town, South Africa. Alternation, 17(2): 146-172.

Chan, C.S., Peters, M. \& Marafa, L.M. 2015. Public parks in city branding: Perceptions of visitors vis-à-vis residents in Hong Kong. Urban Forestry and Urban Greening, 14: 11571165. 
Chiesura, A. 2004. The role of urban parks for the sustainable city. Landscape and Urban Planning, 68(1): 129-138.

City of Cape Town. n.d. Green Point Park Visitor's Guide. Available:

https://www.capetown.gov.za/en/CapeTownStadium3/Documents/Park\%20Visitors $\% 20$ Guide.pdf [2016, May 15].

City of Cape Town. 2006. Proposed: rezoning of a portion of green point common from public open space to community facilities use zone to permit the development of a multipurpose stadium \& ancillary/incidental uses together with the closure of public space, closure of public street, amendment of a schedule 2 condition, consents, temporary departure, departure \& deviation from the green point development framework: portion of remainder erf 1056 at Fritz Sonnenberg Road, Green Point. Cape Town.

City of Cape Town. 2007. The Green Point Common: Have Your Say. City News (Cape Town). April.

City of Cape Town. 2010. Public Parks By-Law. Western Cape Provincial Gazette. Available:

https://www.capetown.gov.za/en/parks/Documents/ByLaw_Public_Parks_2010.pdf [2016, May 15].

City of Cape Town. 2012. Business plan for Cape Town Stadium and Green Point Park: A public information and summary report. Available:

https://www.capetown.gov.za/en/PublicParticipation/Documents/CCT_stadium_plan_we b.pdf [2016, March 15].

Cornelissen, S. \& Swart, K. 2006. The 2010 Football World Cup as a political construct: the challenge of making good on an African promise. In Sports Mega-Events: Social Scientific Analyses of a Global Phenomenon. J. Horne \& W. Manzenreiter. Eds. Oxford: Blackwell Publishing. 108-124.

Cornwall, A. 2008. Unpacking 'Participation': models, meanings and practices. Community Development Journal, 43(3): 269-283. 
Cranz, G. 1982. The Politics of Park Design: A History of Urban Parks in America. Cambridge, MA: MIT Press.

Cranz, G. \& Boland, M. 2004. Defining the sustainable park: A fifth model for urban parks. Landscape Journal, 23(2): 102-120.

Daneshpour, Z.A. \& Mahmoodpour, A. 2009. Exploring the people's perception of urban public parks in Tehran. Proceedings of REAL CORP 2009: Cities 3.0. Sitges. 22-25 April 2009. 687-692. Available:

http://www.researchgate.net/publication/242221046_Exploring_the_people's_perception of_urban_public_p_arks_in_Tehran [2016, February 15].

Davidson, M. 2013. The Sustainable and Entrepreneurial Park? Contradictions and Persistent Antagonisms at Sydney's Olympic Park. Urban Geography, 34(5): 657-676.

Dawson, A. 2006. Geography of Fear: Crime and the Transformation of Public Space in Postapartheid South Africa. In The Politics of Public Space. S.M. Low \& N. Smith. Eds. London: Routledge. 123-142.

Dellenbaugh, M., Kip, M., Müller, A.K. \& Schwegmann, M. Eds. 2015. Urban Commons: Moving Beyond State and Market. Basel: Birkhäuser.

Didier, S., Peyroux, E. \& Morange, M. 2012. The Spreading of the City Improvement District Model in Johannesburg and Cape Town: Urban Regeneration and the Neoliberal Agenda in South Africa. International Journal of Urban and Regional Research, 36(5): 915-935.

Dirsuweit, T. 2007. The production of 'secure' space in new urbanism developments and the democratisation of public space in Johannesburg. Proceedings of the $4^{\text {th }}$ international conference of the research network private urban governance and gated communities. 116. Available: http://www.staff.unimainz.de/glasze/Abstracts_Papers_Paris_2007/Dirsuweit.pdf [2016, February 15].

Doherty, J., Busch-Geertsema, V., Karpuskiene, V., Korhonen, J., O’Sullivan, E., Sahlin, I., Tosi, A., Petrillo, A. \& Wygnańska, J. 2008. Homelessness and Exclusion: Regulating public space in European Cities. Surveillance \& Society, 5(3): 290-314. 
Donaldson, R. 2014. The Production of Quartered Spaces in Stellenbosch. [Inaugural Address]. University of Stellenbosch. 1-16. Available:

http://www.stellenboschheritage.co.za/wp-content/uploads/intreerede-final-email.pdf [2016, February 15].

Fernández Álvarez, R. 2012. Neoliberalism and parks: the urban political ecology of green public space in Mexico City. Sociedad Hoy, 23: 83-115.

Foster, S.R. \& Iaione, C. 2016. The City as a Commons. Yale Law and Policy Review. Available: https://www.academia.edu/15261541/The_City_as_a_Commons [2016, February 15].

Green, L.G. 1948. Cape Town: Tavern of the Seas. Cape Town: Howard Timmins.

Hardin, G. 1968. The Tragedy of the Commons. American Association for the Advancement of Science, 162(3859): 1243-1248.

Harvey, D. 2006. The Political Economy of Public Space. In The Politics of Public Space. S.M. Low \& N. Smith. London: Routledge.17-34.

Horne, J. \& Manzenreiter, W. Eds. 2006. Sports Mega-Events: Social Scientific Analyses of a Global Phenomenon. Oxford: Blackwell Publishing.

Houssay-Holzschuch, M. \& Teppo, A. 2009. A mall for all? Race and public space in postapartheid Cape Town. Cultural Geographies, 16(3): 351-379.

Jarvis, P.K. 2007. Founding Affidavit (Case no. 4051) presented in the High Court of South Africa in the matter between Cape Town Environmental Protection Association (Applicant) and Western Cape Provincial Department of Environmental Affairs and Development Planning (First Respondent), Minister for Environmental Affairs, Planning and Economic Development, City of Cape Town, Building and Planning Development Management City of Cape Town, Federation Internationale Football Association, FIFA 2010 World Cup Organising Committee South Africa, Metropolitan Gold Club: 1-72.

Jerram, L. 2015. The false promise of the commons: historical fantasies, sexuality and the 'really-existing' urban common of modernity. In Urban Commons: Rethinking the City. C. Borch \& M. Kornberger. Eds. New York: Routledge. 47-67. 
Jessop, B. 2002. Liberalism, Neoliberalism, and Urban Governance: A State-Theoretical Perspective. Antipode, 34(3): 452-472.

Katz, C. 2006. Power, Space, Terror: Social Reproduction and the Public Environment. In The Politics of Public Space. S.M. Low \& N. Smith. Eds. London: Routledge. 105-122.

Kimber, J. 2010. 'A nuisance to the community': policing the vagrant woman. Journal of Australian Studies, 34(3): 275-293.

Lamarca, M.G. 2015. Insurgent Act of Being-in-Common and Housing in Spain: Making Urban Commons? In Urban Commons: Moving Beyond State and Market. M. Dellenbaugh, M. Kip, A.K. Müller \& M. Schwegmann. Eds. Basel: Birkhäuser. 165-177.

Lawson, L. 2007. Parks as Mirrors of Community: Design Discourse and Community Hopes for Parks in East St. Louis. Landscape Journal, 26(1): 116-133.

Lemanski, C. 2004. A new apartheid? The spatial implications of fear of crime in Cape Town, South Africa. Environment \& Urbanization, 16(2): 101-112.

Lemanski, C. 2007. Global Cities in the South: Deepening social and spatial polarisation in Cape Town. Cities, 24(6): 448-461.

Loukaitou-Sideris, A. 1995. Urban Form and Social Context: Cultural Differentiation in the Uses of Urban Parks. Journal of Planning Education and Research, 14(2): 89-102.

Low, S.M. 2006. The Erosion of Public Space and the Public Realm: paranoia, surveillance and privatization in New York City. City \& Society, 18(1): 43-49.

Low, S.M. 2011. Claiming Space for an Engaged Anthropology: Spatial Inequality and Social Exclusion. American Anthropologist, 113(3): 389-407.

Low, S.M. \& Smith, N. Eds. 2006. The Politics of Public Space. London: Routledge.

Low, S.M., Taplin, D. \& Scheld, S. 2005. Rethinking Urban Parks: Lessons in Culture and Diversity. Austin: University of Texas Press.

Madden, D.J. 2010. Revisiting the End of Public Space: Assembling the Public in an Urban Park. City \& Community, 9(2): 187-207. 
Marais, I. E. 2013. Public space/public sphere: An ethnography of Joubert Park, Johannesburg. Ph.D. Thesis. University of Johannesburg. Available: https://ujdigispace.uj.ac.za/handle/10210/8447 [2016, February 15].

McConnachie, M.M. \& Shackleton, C.M. 2010. Public green space inequality in small towns in South Africa. Habitat International, 34(2): 244-248.

McConnachie, M.M., Shackleton, C.M. \& McGregor, G.K. 2008. The extent of public green space and alien plant species in 10 small towns of the Sub-Tropical Thicket Biome, South Africa. Urban Forestry \& Urban Greening, 7: 1-13.

McDonald, D.A. \& Smith, L. 2004. Privatising Cape Town: From Apartheid to Neo-liberalism in the Mother City. Urban Studies, 41(8): 1461-1484.

Minton, A. 2006. The privatisation of public space. Available: http://mall.lampnet.org/index.php/filemanager/download/582/UKpublic_space_BID.pdf [2016, February 15].

Miraftab, F. 2004a. Making neo-liberal governance: the disempowering work of empowerment. International Planning Studies, 9(4): 239-259.

Miraftab, F. 2004b. Public-Private Partnerships: The Trojan Horse of Neoliberal Development. Journal of Planning Education and Research, 24(1): 89-101.

Miraftab, F. 2007. Governing Post-Apartheid Spatiality: Implementing City Improvement Districts in Cape Town. Antipode, 39(4): 602-626.

Mitchell, D. 1995. The End of Public Space? People's Park, Definitions of the Public, and Democracy. Annals of the Association of American Geographers, 85(1): 108-133.

Mitchell, D. \& Staeheli, L.A. 2006. Clean and Safe? Property Redevelopment, Public Space, and Homelessness in Downtown San Diego. In The Politics of Public Space. S.M. Low \& N. Smith. London: Routledge. 143-176.

More, T.A. 2005. From Public to Private: Five Concepts of Park Management and Their Consequences. The George Wright Forum, 22(2): 12-20. 
Murray, M. 2010. Private Management of Public Spaces: Nonprofit organisations and urban parks. Harvard Environmental Law Review, 34: 179-255. Available: www.law.harvard.edu/students/orgs/elr/vol34 1/179-256.pdf [2016, February 15].

Narsiah, S. 2013. Neoliberalism as a spatial fix: An example from South Africa. Geoforum, 45: 136-144.

Nasir, M.I., Anuar, M. \& Saruwono, M. 2012. Barriers of User's Involvement in the Design Process of Public Parks as Perceived by Landscape Architects. Procedia - Social and Behavioural Sciences, 35: 253-259.

Nielsen, G.M. 2015. Mediated exclusions from the urban commons: Journalism and poverty. In Urban Commons: Rethinking the City. C. Borch \& M. Kornberger. Eds. New York: Routledge. 127-152.

Parnell, S. \& Pieterse, E. 2010. The 'Right to the City': Institutional Imperatives of a Developmental State. International Journal of Urban and Regional Research, 34(1): 146162.

Patrick, M. \& Clift, H. 2006. Archaeological Impact Assessment Green Point Common Erf 1059, Green Point. Available: http://www.sahra.org.za/sahris/sites/default/files/heritagereports/AIA 1059 Green Poin t_Clift_H_May06_0.pdf [2016, April 15].

Phakathi, B. 2013. Cape Town Stadium's demolition 'not on'. Available: http://www.bdlive.co.za/national/2013/10/04/cape-town-stadiums-demolition-not-on [2016, February 15].

Pollack, M. 2011. Green Point Park officially opened. Available: https://www.capetown.gov.za/en/Pages/GreenPointParkofficiallyopened.aspx [2016, May 15].

Ramoroka, T. \& Tsheola, J. 2014. Gated-communities and the privatization of public spaces in urban South Africa: Democratic social integration or exclusion? Journal of Geography and Regional Planning, 7(4): 58-68. 
Roche, M. 2000. Mega-events and Modernity: Olympics and expos in the growth of a global culture. London: Routledge.

Samara, T.R. 2011. Cape Town after Apartheid: Crime and Governance in the Divided City. Minneapolis: University of Minnesota Press.

Shackleton, C.M. \& Blair, M. 2013. Perceptions and use of public green space is influenced by its relative abundance in two small towns in South Africa. Landscape and Urban Planning, 113: 104-112.

Shuib, K.B., Hashim, H. \& Nasir, N.A.M. 2015. Community Participation Strategies in Planning for Urban Parks. Procedia - Social and Behavioural Sciences, 168: 311-320.

Sorkin, M. 1992. Variations on a Theme Park: The New American City and the End of Public Space. New York: Hill and Wang.

Southworth, B. n.d. City Squares in Cape Town's Townships - Public space as an Instrument of Urban Transformation: The Origins, Objectives and Implementation of the City of Cape Town's Dignified Places Programme. Available:

http://ndp.treasury.gov.za/TTRI/Courses\%20Library/2007,\%2029\%20Oct2\%20Nov\%20-\%20TTRI\%20Overview\%20Course, \%20Midrand/Day \%202\%20\%2030\%20Oct\%202007/Reading\%20-\%20Public\%20Spaces\%20CoCT.pdf [2015, September 15].

Spocter, M.A. 2005. The 'Silent' Privatisation of Urban Public Space in Cape Town, 1975 2004 MA. Thesis. University of the Western Cape. Available: http://etd.uwc.ac.za/xmlui/handle/11394/1690 [2015, September 15].

Staeheli, L.A. \& Mitchell, D. 2008. The People's Property. Power, Politics and the Public. New York: Routledge.

Todeschini and Japha Architects and Planners. 1991. The Green Point Common Master Plan prepared for the Cape Town City Council. Cape Town.

Vainer, C. 2016. Mega-events and the city of exception: theoretical explorations of the Brazilian experience. In Mega-Events and Globalization: Capital and Spectacle in a Changing World Order. R. Gruneau \& J. Horne. Eds. New York: Routledge. 97-112. 
Van Heerden, P. 2008. Chronology of Decisions relating to the formalization of the Green Point Urban Park (GPUP) Site Development Plan and Related Guidelines. (Unpublished).

Van Heerden, P. 2009. Green Point Park-Vision. (Unpublished).

Van Heerden, P. 2012. Green Point Urban Park, Where to from Here? (Unpublished).

Van Heerden, P. 2014. Green Point Urban Park (GPUP and Cape Town Stadium): Turning an under-utilised public open space into an exceptional amenity, Cape Town's fourthmost popular destination. World Design Capital 2014 Internal Projects Showcase. Case Study no. 053. City of Cape Town. Available:

http://www.capetown.gov.za/en/WDC2014/Projects/WDC_project_053.pdf [2016, April $15]$.

Van Papendorp, J. 2010a. Reconstruction of the Green Point Common. Proceedings of the Ilasa Conference. 14 May 2010. Johannesburg.

Van Papendorp, J, 2010b. Green Point Park Overview. (Unpublished).

Van Papendorp, J. 2010c. Reconstruction of Green Point Common. Available: http://static1.1.sqspcdn.com/static/f/477889/6973594/1274169841547/Green+Point+Par

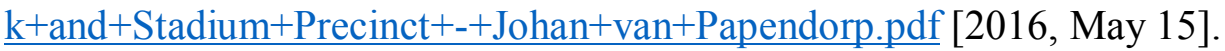

Worden, N., van Heyningen, E. \& Bickford-Smith, V. 1998. Cape Town, The Making of a City: An Illustrated Social History. Kenilworth: David Philip Publishers. 


\section{APPENDIX A \\ Fieldwork Components}

Historical and archival data collection: Cape Town Campus of the National Library of South Africa (5 February 2016) as well as the Special Collections and Government Publication Libraries of the University of Cape Town (1 February 2016).

Participant observation conducted in Green Point Park: Intermittent park visits (20), spanning several hours over weekdays and weekends, from 8 October 2015 to 23 April 2016.

\section{List of formal 'expert' interviews conducted:}

- Interview with Mr Johan van Papendorp (landscape architect), Cape Town, 28.09.2015

- Interview with Mr Richard Mathieson (park facilities manager), Cape Town, 08.10.2015

- Interview with Mr Peter van Heerden (City’s planning director), Cape Town, 05.10.2015

- Email Correspondence with Ms Claudia Scherer (GPRRA committee member), Cape Town, 29.01.2016

- Interview with Mr Luke Stevens (Vice-Chair of GPRRA), Cape Town, 02.02.2016

- Interview with Ms Karen Louise Fletcher (GPRRA committee member), Cape Town, 09.02.2016

- Interview with Ms Jenny McQueen (Chair of GPRRA), Cape Town, 23.02.2016

- Follow-up interview with Mr Peter van Heerden (City's planning director), Cape Town, 23.02.2016

- Follow-up interview with Mr Richard Mathieson (park facilities manager), Cape Town, 15.04.2016

- Interview with Mr James Loock (former Chair of GPRRA), Cape Town, 23.04.2016

- Interview with Mr Marco van Embden (former Chair of MPRA), Cape Town, 18.05.2016

- Interview with Mr David Maralack (former operations manager at City of Cape Town, Sport and Recreation Department), Cape Town, 28.06.2016

- Interview with Ms Desiree Galant (former operations manager at City of Cape Town, Parks Department), Cape Town, 04.07.2016

Informal 'individual interviews: Conducted with eight security guards, four landscapers, three cleaners and ten park users during operating hours of the park (07:00-19:00) from 28 January 2016 to 20 April 2016.

Meetings attended: Annual General Meeting of the GPRRA on 18 May 2016.

Transect walk in Green Point Park: Conducted with Mr Richard Mathieson (park facilities manager), Cape Town, 15.04.2016.

Ethics approval code from Faculty of Science: FSREC 51 - 2015 